\title{
1 Investigation on the near-field evolution of industrial plumes from metalworking activities
}

3

Ari Setyan ${ }^{1, a, b, *}$, Pascal Flament ${ }^{1, *}$, Nadine Locoge $^{2}$, Karine Deboudt $^{1}$, Véronique Riffault ${ }^{2}$, Laurent Y. Alleman ${ }^{2}$, Coralie Schoemaecker ${ }^{3}$, Jovanna Arndt ${ }^{4}$, Patrick Augustin ${ }^{1}$, Robert M. Healy ${ }^{4, c}$, John C. Wenger ${ }^{4}$, Fabrice Cazier ${ }^{5}$, Hervé Delbarre ${ }^{1}$, Dorothée Dewaele ${ }^{5}$, Pascale Dewalle $^{3, d}$, Marc Fourmentin ${ }^{1}$, Paul Genevray ${ }^{5}$, Cyril Gengembre ${ }^{1}$, Thierry Leonardis ${ }^{2}$, Hélène Marris $^{1, \mathrm{e}}$, Saliou Mbengue ${ }^{2, \mathrm{f}}$

${ }^{1}$ Laboratoire de Physico-Chimie de l'Atmosphère, Université du Littoral Côte d'Opale, EA 4493-CNRS, 59140 Dunkerque, France

${ }^{2}$ Département Sciences de l'Atmosphère et Génie de l'Environnement - SAGE, IMT Lille Douai, Université de Lille, 59000 Lille, France

${ }^{3}$ Laboratoire de Physico-Chimie des Processus de Combustion et de l'Atmosphère, Unité Mixte de Recherche CNRS-Université Lille1 Sciences et Technologies (UMR 8522), 59655 Villeneuve d'Ascq, France

${ }^{4}$ School of Chemistry and Environmental Research Institute, University College Cork, Cork, Ireland

${ }^{5}$ Centre Commun de Mesures, Université du Littoral Côte d'Opale, 59140 Dunkerque, France

a now at: Empa, Swiss Federal Laboratories for Materials Science and Technology, Laboratory for Advanced Analytical Technologies, 8600 Dübendorf, Switzerland

${ }^{\mathrm{b}}$ now at: ETH Zürich, Institute of Environmental Engineering, 8093 Zürich, Switzerland

c now at: Environmental Monitoring and Reporting Branch, Ontario Ministry of the Environment, Conservation and Parks, Ontario, Canada

${ }^{\mathrm{d}}$ now at: Unité de Catalyse et Chimie du Solide, Unité Mixte de Recherche CNRS-Université Lille1 Sciences et Technologies (UMR 8181), 59655 Villeneuve d'Ascq, France

${ }^{\mathrm{e}}$ now at: Sotrenor, 62710 Courrières, France

${ }^{\mathrm{f}}$ now at: CzechGlobe - Global Change Research Institute, 60300 Brno, Czech Republic

*Correspondence to: Ari Setyan (ari.setyan@gmail.com)

Pascal Flament (pascal.flament@univ-littoral.fr)

\section{Postal address}

Prof. Pascal Flament

Université du Littoral Côte d'Opale

Laboratoire de Physico-Chimie de l'Atmosphère - EA 4493

MREI 2 - 189A Avenue Maurice Schumann 
3859140 Dunkerque

39

$40 \quad$ Tel : +33(0)32823 7644

$41 \quad$ Fax : +33(0)328658244

42

43 


\section{Abstract}

In a context where a significant fraction of the population lives near industrial areas, the main objectives of this study are to provide (a) new data on $\mathrm{PM}_{2.5}$ chemical compositions, heavymetal concentrations and trace gases released by metalworking activities and (b) new information on the near-field evolution (up to about a thousand meters) of such industrial plumes in terms of particle chemical composition and size distribution. For that purpose, a one-month field campaign was performed in an industrial area near the city of Dunkirk (Northern France), combining measurements of atmospheric dynamics and physico-chemical characterization of air masses. Comparisons between several elemental ratios (mainly $\mathrm{Mn} / \mathrm{Fe}$ ), particle size distributions and volatile organic compound (VOC) concentrations at the stacks and at a near-field site suggest that plumes of a ferromanganese alloy plant were quickly mixed with pollutants emitted by other sources (mainly other industries, possibly traffic and sea spray), in particular a neighboring steelworks, before reaching the sampling site. This led to the emergence of secondary particles related to condensation and/or aggregation phenomena inside the plumes. Metalworking emissions were also identified as a source of new particle formation, formed through the emission of gaseous precursors and their fast transformation and condensation, over a timescale of minutes before reaching the near-field site $800 \mathrm{~m}$ downwind. Ultrafine particles emitted at the stacks also quickly agglomerated to form larger particles before reaching the near-field site. These results show that, even over short distances, the chemical composition and size distribution of metalworking plumes may evolve rapidly and the characteristics of particles at the boundary of an industrial area (especially in contiguous urban areas) may differ from those emitted directly at the stacks. 
$67 \quad$ Keywords

68 Fine particles

69 Volatile organic compounds

70 Industrial emissions

71 Plume evolution

72 Atmospheric dynamics

73 


\section{Introduction}

Epidemiological studies have demonstrated that exposure to atmospheric pollution has adverse effects on human health, such as cardiovascular (Brook et al., 2004) and pulmonary (Oberdörster, 2000) diseases and cancer (Pope et al., 2011). In particular, particles smaller than $2.5 \mu \mathrm{m}\left(\mathrm{PM}_{2.5}\right)$ are more dangerous than coarse ones $\left(\mathrm{PM}_{2.5-10}\right)$, because the former can penetrate deeper into the lungs, reach the alveoli and enter the cardiovascular system (Kelly and Fussell, 2011). According to the Clean Air for Europe (CAFE, see Table S1 in the supplementary material for acronyms) program, the average decrease of life expectancy in Europe due to exposure to $\mathrm{PM}_{2.5}$ is nine months, but increases to $12-36$ months in Benelux and in the north-east area of France (2005). However, many uncertainties still remain on the identity of chemicals in the particle phase, their mixing state (which may lead to synergy in terms of toxicity) and source inventories for fine particles bearing toxic chemicals.

Previous studies have shown that industrial activities release large quantities of both gaseous and particulate matter into the atmosphere. The physico-chemical nature of particles emitted by industry has already been reviewed (Riffault et al., 2015; Sanderson et al., 2014; Taiwo et al., 2014). A high variability of chemical composition and size distribution can be observed depending on the type of industrial processes involved. Nevertheless, tracers of specific industrial activities, such as heavy metals (Dall'Osto et al., 2008; Wong et al., 2006; Yang et al., 2018), the organic-to-elemental carbon ratio (OC/EC) (Chow et al., 2011), diagnostic ratios or concentrations of some specific polycyclic aromatic hydrocarbons (PAHs) (Katsoyiannis et al., 2011; Leoni et al., 2016), secondary inorganic species such as ammonium sulfate, nitrate, and chloride (Setyan et al., 2017; Wu et al., 2018), and the carbon preference index (CPI, defined as the ratio of the sum of odd carbon number of $n$-alkanes to the sum of even carbon number of n-alkanes) (Fraser et al., 2002; Li et al., 2010) have been 
identified as a means by which to provide estimates of the relative contribution of pollutant sources from heavily industrialized regions. Many industrial activities emit a range of PAHs, volatile organic compounds (VOCs) and inorganic gases including $\mathrm{NO}_{\mathrm{x}}$ and $\mathrm{SO}_{2}$. For instance, selected industrial processes in steelworks, such as coke production, iron ore sintering (Ciaparra et al., 2009), and electric arc furnaces (Baraniecka et al., 2010), release large amounts of PAHs. Coke ovens, commonly used in steelworks, also emit significant concentrations of VOCs (Lin et al., 2007).

In this context, our NANO-INDUS project had two main objectives: 1) to produce new data on $\mathrm{PM}_{2.5}$, carbonaceous particles, heavy-metal concentrations and trace gases released by metalworking activities; and 2) to provide new information on the chemical composition, mixing state and source identification of industrial atmospheric particulate matter.

In terms of atmospheric processes, NANO-INDUS was motivated by three inter-related questions:

1) How much do the physico-chemical characteristics of atmospheric fine particles at the boundary of a metalworking industrial complex differ from those directly emitted from the stacks?

2) Is there a link between the presence of fine particles at the boundary of this site and gases directly emitted from the stacks?

3) Do fine particles within a metalworking plume have a homogeneous chemical composition as essentially primary particles, or are they produced or evolving by condensation and/or agglomeration, leading to secondary particles with heterogeneous compositions?

To help address these questions, a field campaign was conducted at an industrial site close to the Dunkirk metropolitan area (Grande-Synthe). This region is highly industrialized and the 
121 particle concentrations regularly exceed the World Health Organization annual mean 122 guideline value of $10 \mu \mathrm{g} \mathrm{m}{ }^{-3}$ for $\mathrm{PM}_{2.5}$ (World Health Organization, 2006). Of particular 123 interest is the industrial area of Grande-Synthe, which is comprised of various industries (steel 124 industry, metallurgy, smelting works, chemical industry, refineries, food-processing industry, 125 power production, cement works) (DREAL, 2011) located $7 \mathrm{~km}$ from downtown Dunkirk. 126 Following the diversity of industrial activities at this location, Grande-Synthe is very similar 127 to many other industrial areas throughout the world, where industrial emissions had also been 128 studied in previous publications, e.g. at Port Talbot (United Kingdom) (Dall'Osto et al., 2008), 129 Taranto (Italy) (Amodio et al., 2014), and Hangzhou in the Yangtze River Delta (China) (Dai 130 et al., 2015). Previous studies have also been performed within the industrial park of Grande131 Synthe (Cazier et al., 2016; Crenn et al., 2017; Mbengue et al., 2015). Particulate metal 132 content has been extensively studied, due to the importance of steelworks and metallurgy at 133 Grande-Synthe (Alleman et al., 2010; Arndt et al., 2016; Flament et al., 2008; Hleis et al., 134 2013; Kfoury et al., 2016; Landkocz et al., 2017; Marris et al., 2012; Marris et al., 2013; 135 Mbengue et al., 2014; Mbengue et al., 2017; Santos et al., 2016). A number of elements or 136 elemental ratios have been used as tracers for specific sources within the industrial area, e.g. $137 \mathrm{Mn}$ or $\mathrm{Mn} / \mathrm{Fe}$ ratio for emissions from the ferromanganese alloy factory (Marris et al., 2012), $138 \mathrm{~Pb}$ and $\mathrm{Fe}$ isotopes for steelworks emissions (Flament et al., 2008), $\mathrm{V}$ and $\mathrm{Ni}$ for 139 petrochemistry (Alleman et al., 2010), Fe, $\mathrm{Ca}, \mathrm{Al}$ and $\mathrm{Mn}$ for selected iron and steel processes 140 such as sintering, blast furnace, steelmaking and desulfurization slag processing (Hleis et al., 141 2013). A few studies have also focused on the measurement of VOCs in this area. For 142 instance, Badol et al (Badol et al., 2008a; Badol et al., 2008b) identified specific industrial 143 activities as important sources of benzene (metallurgical, steel industries), octane (lubricant 144 storage), pentane (hydrocarbon storage), and propene (hydrocarbon cracking). Roukos et al. 
145 (2009) measured BTEX (benzene, toluene, ethylbenzene, xylene) during two contrasting

146 seasons. In winter, BTEX concentrations were mainly due to local pollution, while in

147 summer, they decreased because of photochemical activity and the influence of continental

148 aged air masses, highlighting the fact that even in anthropogenically-influenced areas, long-

149 range transport can have a significant contribution to the observed concentrations. Finally,

150 Xiang et al. (2012) emphasized the influence of vertical turbulence on the dispersion of VOCs

151 at the local scale.

152 The aim of the present paper is to give an overview of the measurements performed during

153 the NANO-INDUS project, and to present the main findings of this study. First, we will

154 present results obtained during the intensive field campaign performed at the near-field

155 sampling site, and those obtained during the samplings at the stacks. Then, physico-chemical

156 characteristics of particles measured when the near-field sampling site was impacted by

157 plumes from the Fe-Mn plant will be compared to particles measured during periods from

158 other influences (petrochemistry, urban emissions).

1602 Experimental

\section{$161 \quad 2.1 \quad$ Sampling site}

162 All sampling and measurements took place next to the site of a ferromanganese alloy

163 manufacturing facility (Fe-Mn plant), located in the industrial area of Grande-Synthe, $\sim 2 \mathrm{~km}$

164 west of the Dunkirk metropolitan area and $\sim 7 \mathrm{~km}$ from the city center $\left(51^{\circ} 01^{\prime} 44^{\prime \prime}\right.$ north, $2^{\circ}$

$16516^{\prime} 10^{\prime \prime}$ east, $10 \mathrm{~m}$ above sea level). Figure 1a shows a map of the area with the sampling site 
166 located centrally within the industrial zone of Grande-Synthe and $\sim 800 \mathrm{~m}$ southwest of the

167 emission chimneys in the Fe-Mn plant.

168 Atmospheric composition at the sampling site can be influenced by a variety of different 169 emission sources, depending on the wind direction. Pollutant sources to the east of the 170 sampling site are mainly industrial in origin due to the presence of a large steelworks $(<1$ $171 \mathrm{~km}$ ), but also urban-influenced due to Fort-Mardyck (3'600 inhabitants, $\sim 2 \mathrm{~km}$ from the 172 sampling site) and Dunkirk (93’000 inhabitants, $\sim 7 \mathrm{~km}$ from the site). The North Sea is only 1

$173 \mathrm{~km}$ to the north and northwest, bringing marine and ship emissions to the site. Approximately $174200 \mathrm{~m}$ to the north of the site is an outdoor storage area for manganese ores which is a 175 potential source of dust during windy periods. Finally, pollutant sources to the west 176 (petrochemistry, glass production) and southwest (refineries) of the site also mainly originate 177 from industrial activities.

178 The Fe-Mn plant receives iron-enriched manganese ores by boat, and transforms these ores 179 into a ferromanganese alloy, which is used in steelworks to improve the mechanical properties 180 of steel. Figure 2 shows a schematic drawing of the production process. In the first step, 181 manganese ores are sintered with anthracite and calcite $\left(\mathrm{CaCO}_{3}\right)$ in an oven. This step 182 involves heating of the sinter, followed by cooling. In the second step, the manganese ore 183 included in the sinter is reduced into metallic Mn in an electric arc furnace, which provides 184 the necessary energy for the redox reaction. The third and last step consists of crushing the 185 alloy to obtain the final product. Particles and gases emitted during these steps are collected in 186 three different chimneys, in which they are treated by filters before their release into the 187 atmosphere. Two of these chimneys are located in the sintering unit, above the firing and the 188 cooling areas, respectively, while the third chimney is in the smelting unit. The sintering unit 189 works 24 hours a day with particles and gases continuously emitted from its two chimneys. 
190 Emissions from the smelting unit, where electrochemical reduction of the manganese ore and

191 casting of the final product takes place, occur about once every six hours.

192

193

194

195

196

197

198

199

200

201

202

203

204

205

206

207

\subsection{Instrumentation}

The field campaign took place between May 15 and June 12, 2012. The complete list of instruments deployed during this field campaign is given in Table S2. Local meteorological parameters were measured using a weather station (Davis Instruments, Hayward, CA; model Vantage Pro 2) and a sonic anemometer (METEK GmbH, Elmshorn, Germany; model USA1). A Doppler sonic detection and ranging (SODAR; Remtech, Vélizy, France; model PA2) instrument was used to determine turbulence and vertical profiles of the wind components. An aerosol light detection and ranging (LIDAR; Raymetrics S.A., Paiania, Greece) instrument was installed near the sampling site (Figure 1b). Every 15 minutes, the LIDAR scanned in four different directions, and the backscattered light was used to determine the particle abundance as a function of the altitude and the distance from the instrument.

A large suite of instruments was set up to characterize the concentration, chemical composition and size distribution of particles with a high time resolution ( $\sim 5$ minutes $)$. These instruments were connected to a common isokinetic particle sampler (Alfaro et al., 2003) operated at $52 \mathrm{~m}^{3} \mathrm{hr}^{-1}, 7 \mathrm{~m}$ above ground level. The Particle Loss Calculator (von der Weiden et al., 2009) was used to calculate particle loss across the sampler (Figure S1 in the supplementary material). The cut-off size of the sampling line was $2.5 \mu \mathrm{m}\left(\mathrm{PM}_{2.5}\right)$, assuming an average particle density of $2.5 \mathrm{~g} \mathrm{~cm}^{-3}$ based on the measured chemical composition. This high particle density is due to the fact that the sampling site was impacted by a high fraction of sea salts, metal oxide particles (Fe, Mn, Al), and $\mathrm{CaCO}_{3}$ (see Section 4.1). A highresolution time-of-flight aerosol mass spectrometer (HR-ToF-AMS; Aerodyne Research Inc., 
213 Billerica, MA) (Canagaratna et al., 2007; DeCarlo et al., 2006) measured the chemical 214 composition and size distribution of non-refractory submicron particles $\left(\mathrm{NR}-\mathrm{PM}_{1}\right)$ in the 215 range 50-1000 $\mathrm{nm}$ (in vacuum aerodynamic diameter, $D_{v a}$ ). Since this instrument uses a 216 thermal method to vaporize aerosol species, refractory materials, such as black carbon, sea 217 salt and most metallic species, cannot be detected with this technique. An aerosol time-of218 flight mass spectrometer (ATOFMS; TSI Instruments Ltd., High Wycombe, U.K.; model 219 3800-100) (Arndt et al., 2016; Gard et al., 1997) simultaneously measured single particle 220 composition and mixing state in the size range $100-3000 \mathrm{~nm}$ (in $D_{v a}$ ). The ATOFMS 221 vaporizes aerosol species by laser ablation, enabling the measurement of refractory species, 222 which are expected to play a significant role in the particle chemistry at this industrial site. 223 Over 700'000 single particle mass spectra were collected during the campaign and clustered 224 using the $\mathrm{K}$-means algorithm $(\mathrm{K}=90)$, as described in detail elsewhere (Gross et al., 2010; 225 Healy et al., 2010; Healy et al., 2009). A 2-wavelength Aethalometer (Magee Scientific, 226 Berkeley, CA; model AE42) was deployed to measure organic-like (OC) and black carbon 227 (BC) concentrations via the measurement of absorption coefficients at 370 and $880 \mathrm{~nm}$, 228 respectively. The algorithm presented by Weingartner et al. (2003) was used to reduce 229 measurement artifacts due to filter loading and the scattering of the light beam in the filter 230 matrix. Two scanning mobility particle sizers (SMPS) and an optical particle counter (OPC) 231 were used to measure the particle size distribution. The first SMPS system (Grimm Aerosol 232 Technik, Ainring, Germany) was comprised of a differential mobility analyzer (DMA; model 233 55-900) and a condensation particle counter (CPC; model 5.403), enabling particle counting 234 in the size range 10-1000 nm (in mobility diameter, $D_{m}$ ), while the second SMPS (TSI Inc., 235 Shoreview, MN) was constituted of a CPC model 3010, an electrostatic classifier model 3080, 236 and a DMA model 3081, enabling particle counting in the size range 10-480 nm (in $D_{m}$ ). The 
OPC (Grimm Aerosol Technik; model 1.108) measured particles in the size range $300 \mathrm{~nm}$ -

$23820 \mu \mathrm{m}$ (in optical diameter).

239 In addition to the above-mentioned instruments for online particle measurements, several 240 cascade impactors (Dekati Ltd., Tampere, Finland; 13-stage low pressure impactor, and 3241 stage $\mathrm{PM}_{10}$ impactors) and a speciation sampler (Thermo Fisher Scientific, Waltham, MA; 242 model Partisol 2300) were also deployed to sample particles on filters for subsequent off-line 243 analyses. These results, some of which have already been published (Mbengue et al., 2014), 244 included the measurement of metals by inductively-coupled plasma mass spectrometry 245 (ICP/MS) (Varian Inc., Santa Clara, CA; model 820-MS; or Perkin Elmer, Waltham, MA; 246 model DRC Elan 6100) and by inductively-coupled plasma atomic emission spectroscopy 247 (ICP/AES) (IRIS Intrepid, Thermo-Scientific), and organic carbon (OC) and elemental carbon 248 (EC) by a thermal-optical method (Sunset Laboratory, Tigard, OR; Lab OC-EC aerosol 249 analyzer).

250 A proton transfer reaction time-of-flight mass spectrometer (PTR-ToF-MS) (Kore 251 Technology Ltd, Ely, Cambridgeshire, U.K.; model Series I) (de Gouw and Warneke, 2007; 252 Lindinger et al., 1998) allowed for measurement of VOCs with a proton affinity higher than 253 that of water. Long-chain alkanes and aldehydes $\left(>\mathrm{C}_{8}\right)$ were sampled on adsorbing cartridges 254 with an automatic sampler, and analyzed after thermal desorption by gas chromatography 255 coupled to a mass spectrometer (GC/MS) (Agilent Technologies Inc., Santa Clara, CA; GC: 256 model 6890N; MS: model 5975) following a procedure previously developed and validated 257 (Detournay et al., 2011). Finally, automatic analyzers were used to monitor $\mathrm{CO}_{2}(\mathrm{Horiba} \mathrm{Ltd}$, 258 Kyoto, Japan; model VA-3000) as well as CO (model CO 12M), $\mathrm{NO}_{\mathrm{x}}(\operatorname{model} \mathrm{AC} 31 \mathrm{M}), \mathrm{O}_{3}$ 259 (model $\mathrm{O}_{3} 41 \mathrm{M}$ ), and $\mathrm{SO}_{2}$ (model $\mathrm{AF} 22 \mathrm{M}$ ), all from Environnement S.A., Poissy, France. 
Sampling at the stacks of the ferromanganese alloy production facility was performed using

261 automatic analyzers for gases $\left(\mathrm{SO}_{2}, \mathrm{CO}, \mathrm{NO}_{\mathrm{x}}\right)$, cascade impactors and adsorbing cartridges 262 for collection of particles and VOCs/PAHs for subsequent off-line analysis (Table S3). PM

263

264 was collected in the flues of each stack (downstream of the industrial filters) by installing a 3stage cascade impactor (Dekati Ltd) into the center of the chimney flue. The impactor was equipped with a vertical $\mathrm{PM}_{10}$ sampling head and the sampling rate was adapted to the stack flue in order to obtain an isokinetic sample. This sampling meets European standards for stack dust sampling for emission controls. More details can be found elsewhere (Arndt et al., 2016; Mbengue et al., 2014).

Date and time are reported in Coordinated Universal Time (UTC). The local time during this study was Central European Summer Time (CEST), which corresponds to UTC+2:00.

\section{Meteorology}

\subsection{Meteorological conditions and atmospheric dynamics}

Figure 3 shows the time series of standard meteorological parameters (temperature, relative humidity, solar radiation, rainfall, wind direction and speed) observed during the measurement period, along with atmospheric stability, while back trajectory analysis is presented and discussed in the supplementary material (Figures S2-S4). The temperature varied between 6 and $24^{\circ} \mathrm{C}$, but for most of the field campaign, was in the range $10-15^{\circ} \mathrm{C}$. The maximum solar radiations were in the range $750-850 \mathrm{~W} \mathrm{~m}^{-2}$. Several occasional rainy periods occurred during the field campaign, especially after June 2. The relative humidity was rather high (mean $\pm 1 \sigma: 78.9 \pm 14.3 \%$ ) due to the coastal location of the receptor site. 
The wind direction was an important parameter to identify periods during which the site was

283 under the influence of metalworking emissions, and in particular when NE winds could 284 transport plumes from the emission stacks of the Fe-Mn plant to the sampling site. The wind 285 direction was variable during the field campaign, as shown by the wind rose plot (Figure 1c). 286 Three dominant wind directions each with an occurrence rate of 15-20\% were observed, 287 corresponding to winds blowing from the southwest, northwest, and north. The wind was 288 northeasterly for about $5 \%$ of the field campaign, and we identified two periods during which 289 the plume could be transported to the site from this direction: May 25-27, and June 2. The 290 period between May 25 and 27 was the longest period with a NE wind, corresponding to the 291 hottest days of the campaign and elevated solar irradiation $\left(\sim 800 \mathrm{~W} \mathrm{~m}^{-2}\right)$, which could 292 increase photo-oxidation and promote relatively faster chemical transformations of particles 293 and precursor gases between the emission stacks and the sampling site. Moreover, a high 294 temperature gradient also promotes sea breezes, and thus a vertical mixing of the plumes (see 295 below).

296 During these NE wind periods, it is important to assess the stability of the atmosphere, which 297 describes the mixing of emissions over a large area and explain the vertical and horizontal 298 dispersion of the plume. In the current study, the Monin-Obukhov length scale (deduced from 299 the sonic anemometer), which depends mainly on heat and momentum fluxes, friction 300 velocity and temperature, has been used to estimate the atmospheric stability classes (Stull, 301 1988). Figure $3 d$ shows the time series of the atmospheric stability during the whole 302 campaign. High occurrences of unstable periods were observed and represent $\sim 47 \%$ and $17 \%$ 303 of unstable and very unstable atmospheric conditions, respectively, thus favoring plume 304 dispersion. Moreover, LIDAR measurements can confirm this dispersion effect, and that 305 plumes effectively reach the sampling site during NE wind periods (see below). 
Winds were blowing from NW to NE on 18 days during the campaign, while 11 sea breeze

307 events were also observed. Sea breezes have been frequently observed at Dunkirk during 308 previous studies (Boyouk et al., 2011; Roukos et al., 2011; Talbot et al., 2007). Sea breeze 309 coming from the sea toward the land may modify the lower troposphere stratification by the 310 formation of a thermal internal boundary layer (TIBL) (Augustin et al., 2006). The TIBL is a 311 thin unstable layer where pollutants can be trapped and mixed. Furthermore, since the

312 SODAR echo depends on fluctuation of temperature due to the signature of the boundary 313 layer top, the TIBL top, characterized by high echo values, can be detected (Beyrich, 1997). 314 During the present campaign, the NE wind period between May 25 and May 27 is of 315 particular interest, because according to the wind direction and wind speed time-height 316 sections from the SODAR (Figure 4a), these three days are characterized by long sea breeze 317 events (e.g. on May 25 from 10:00 am to 8:00 pm, on May 26 from 9:00 am to 8:00 pm, and 318 on May 27 from 11:00 am to 8:00 pm), with winds at ground level coming mainly from the 319 NE and likely transporting plumes from the Fe-Mn plant to the sampling site. According to

320 Figure $4 \mathrm{e}$, these sea breeze events are also characterized by an increase in the concentration of 321 particulate phase organics and ammonium nitrate, and a decrease in the concentration of 322 sulfate. These results suggest that organics and ammonium nitrate could possibly be emitted 323 by metalworking activities.

\section{$324 \quad 3.2 \quad$ Detection and monitoring of metalworking plumes}

325 Ground-based remote sensing instruments (SODAR and LIDAR) were used to monitor the propagation of metalworking plumes in the vicinity of the sampling site. Figure 4 includes the SODAR, LIDAR, AMS, Aethalometer, and SMPS data during the period 25-27 May when the winds were from the NE and sea breezes were observed, while Figure S5 shows a few 
examples of LIDAR vertical scans for four relevant directions. The LIDAR data shown in

330 Figures $4 \mathrm{~b}$ and $\mathrm{S} 5$ correspond to the depolarization ratio at $355 \mathrm{~nm}$, i.e. the ratio between the 331 measured perpendicular and parallel backscattered LIDAR signals. This parameter provides 332 information in order to distinguish spherical (e.g. haze) from non-spherical particles (e.g. dust 333 and smoke) in the atmosphere. For example, non-spherical particles as industrial dust (e.g. fly 334 ash from metalworking or steelworks) can depolarize LIDAR signals, resulting in high 335 depolarization ratio values. The higher $355 \mathrm{~nm}$-depolarization ratios were observed during 2533627 May sea breeze events (Figure 4b), clearly indicating that during these precise time slots our sampling site was influenced by metalworking plumes.

338 To confirm the identification of periods during which the sampling site was specifically 339 impacted by these plumes, a two-steps analysis of SODAR and LIDAR data was performed.

340 First, the SODAR data (Figure 4a) was used to determine periods during which the wind at 341 ground level was coming from the NE. Then, the LIDAR data for these periods (Figures $4 \mathrm{~b}$ 342 and S5) was used to determine whether the sampling site was under the influence of the 343 plumes, as well as to confirm the origin of these plumes. For instance, Figure S5d shows a 344 LIDAR vertical scan measured toward an azimuth angle of $228^{\circ}$, corresponding to the 345 direction of the sampling site (Figure S5e). This scan shows that a plume was located very 346 close to the sampling site. LIDAR scans measured less than an hour earlier toward the stacks 347 (azimuth angle $13^{\circ}$, Figure S5a) and the azimuth angles $308^{\circ}$ (Figure S5b) and $238^{\circ}$ (Figure 348 S5c) helped us to determine that the plume was mainly coming from the stacks of the Fe-Mn 349 plant, possibly mixed with emissions from the nearby steelworks. 


\section{Results and discussion}

352

353

354

355

356

357

358

359

360

361

362

363

364

365

366

367

368

369

370

371

372

373

\subsection{Particle chemical composition}

Figure $5 \mathrm{~b}$ shows the time series of the five NR-PM 1 species measured by the HR-ToF-AMS, along with $\mathrm{BC}$ measurements from the Aethalometer. The average NR-PM $\mathrm{P}_{1}$ concentration during the study was $10.7 \mu \mathrm{g} \mathrm{m}^{-3}$. This mean value, taking only NR-PM 1 into account, slightly exceeds the WHO recommendations $\left(10 \mu \mathrm{g} \mathrm{m}^{-3}\right)$. Concentrations were very high between May 24 and May 27 (in the range 20-75 $\mu \mathrm{g} \mathrm{m}^{-3}$ ), but decreased significantly after June 5 (below $5 \mu \mathrm{g} \mathrm{m}^{-3}$ ). According to meteorological conditions and atmospheric dynamics during these periods (Section 3), high mass loadings were concurrent with low wind speed coming from the northeast and east (metalworking activities sector), while the decrease in particle mass loading during the last week occurred when the wind speed increased significantly and wind direction shifted to the south, bringing a few rain episodes. NR-PM 1 was dominated by inorganic species, which accounted for $\sim 2 / 3$ of the total mass, while organics accounted for $\sim 1 / 3$ (Figure 5, upper pie chart). However, the chemical composition varied significantly throughout the study, and several pollution events dominated by ammonium nitrate, ammonium sulfate or organics were observed, especially downwind of metalworking emissions. Despite the fact that very few studies emphasized the contribution of nonrefractory submicron aerosols $\left(\mathrm{NR}-\mathrm{PM}_{1}\right)$ to metalworking (steel industry, metallurgy, smelting works) emissions (Almeida et al., 2015; Crenn et al., 2017), this confirms the importance of secondary aerosols in these emissions. We also observed several periods with an increase in the non-refractory chloride concentration up to $\sim 5 \mu \mathrm{g} \mathrm{m}^{-3}$. This chloride does not correspond to sea salt, given that the AMS, operated in standard conditions (with the vaporizer set at $600^{\circ} \mathrm{C}$ ), cannot evaporate and measure $\mathrm{NaCl}$. Examination of the dependence 
of chloride mass concentrations upon wind direction indicates that this species was observed only during NE wind periods, i.e. when the sampling site was under the direct influence of the 376 Fe-Mn plant and the adjacent steelworks. Moreover, chloride was found to be very well correlated with the $\mathrm{K}^{+}$fragment of the AMS $\left(\mathrm{r}^{2}=0.67\right)$, suggesting that chloride was mainly present in the form of $\mathrm{KCl}$. This might be due to the high formation of $\mathrm{KCl}$ during the sintering process in steelworks (Hleis et al., 2013; Ji et al., 2017; Peng et al., 2009) and is consistent with previous observations using the same instrument at a nearby location (Crenn et al., 2017). Thus, the non-refractory chloride signal may be a useful proxy to determine periods during which a receptor site is under the influence of emissions from steelworks.

This is confirmed by complementary data obtained using the ATOFMS (Figure 5c), which identified 34 distinct particle classes that were subsequently grouped into 10 general 385 categories for clarity. Sea salt particles dominated the dataset by number $(24.4 \%$ of total 386 spectra), followed by K-containing particles (23.2\%) and EC (23.1\%). The remaining particle 387 classes correspond to Fe-containing (5.0\%), Ca-containing (1.7\%), OC and PAH-containing 388 (1.7\%), V-containing (1.4\%), Mn-containing (1.2\%), Pb-containing (1.1\%), and other metals 389 (17.1\%, including $\mathrm{Zn}$ and, in addition, $\mathrm{S}$ - and amine-containing particles). Most particle 390 classes are associated with industrial sources (Arndt et al., 2016), based on their composition 391 and wind dependence. K-containing particles are usually associated with biomass burning 392 sources, especially in winter in this region, however domestic wood burning is expected to be 393 negligible at this time of year (May/June). The significant abundance of K-containing 394 particles is consistent with the high signal for non-refractory chloride observed by the AMS 395 and confirms the importance of steelworks sintering emissions containing KCl. EC particle 396 numbers increased towards the end of the sampling period, while OC and PAH-containing 397 particles were detected in their largest numbers on June 2. EC-containing particles were more 
plentiful during E-NE wind periods (Figure 5a-c), i.e. when the sampling site was more

399 specifically under the influence of the nearby coke production facility of the integrated 400 steelmaking plant. Weitkamp et al. (2005) showed that elemental carbon contributes up to 30 401 wt.\% to coke production emissions. Ca-containing, Fe-containing and Mn-containing particles clearly increase on May 25, 26 and 27 (downwind of the metalworking emissions), while the latter two categories (Fe- and Mn-containing particles) also increased sharply on May 17, 404 under the influence of urban emissions. Given their composition and size, particles in these 405 categories are almost certainly emitted by either the ferromanganese alloy production plant or 406 the neighboring steelworks. This is supported by the fact that these particles are detected in 407 higher numbers during periods when meteorological conditions were most favorable for 408 plumes to be transported from these two plants, as monitored by LIDAR sensing (see Section 409 3.2). Further discussion and interpretation of the ATOFMS data, including the other metals 410 category, will be the subject of future publications.

411 Figure 6 represents the time series of size-resolved elemental composition, determined by 412 ICP/MS and ICP/AES analysis of filters collected using a 13-stage impactor with a time 413 resolution of 24 or 48 hours, while Figure 7 a shows the time series of the mass concentration. 414 The concentration of the following elements increased significantly during the periods May 415 25-27 and June 1-3, when the wind was predominantly coming from the metallurgical 416 complex (NE winds): $\mathrm{Fe}, \mathrm{Mn}, \mathrm{Ca}, \mathrm{K}, \mathrm{Zn}, \mathrm{Pb}$, plus a few minor elements (Cu, Ti, Ba, Rb, Sr). 417 The size distribution indicates that some elements are enriched in the submicron fractions, (K, $418 \mathrm{Zn}, \mathrm{Pb}, \mathrm{V}, \mathrm{Ni}, \mathrm{Cr}, \mathrm{Rb}, \mathrm{Mo}, \mathrm{As}, \mathrm{Cd}, \mathrm{Sb}$ ), while others are more abundant in the coarse fraction 419 (Fe, Ca, Mn, Ti, Ba, Sr), depending on the wind direction. The fact that both $\mathrm{Mn}$ and Fe, 420 abundant downwind of ferromanganese- and steelworks-emissions, were more concentrated 421 in the coarse fraction may be due to a combination of (i) the resuspension of dust from the 
iron-enriched manganese ores stored outdoors (Figure 1b), (ii) industrial mechanical

423

424

processes (excavating, crushing or ore pile processing), in addition to stationary emissions (sintering, etc.), and (iii) road dust resuspension in the harbor area. The comparison between elemental ratios at the emission stacks of the Fe-Mn alloy plant and at the sampling site has been used to confirm periods during which the sampling site was under the influence of emissions from this plant (Table 1). Among the three plant stacks, the one located above the cooling area of the sintering unit (stack B, Figure 2) was by far the most important emitter of fine particles (Arndt et al., 2016), 4 times more than stack A (firing area) and 50 times more than stack $\mathrm{C}$ (smelting unit) (Figure $7 \mathrm{~b}$ ). Given that the plant was manufacturing ferromanganese alloy, the most suitable proxy for our analysis is the $\mathrm{Mn} / \mathrm{Fe}$ ratio (Marris et al., 2012). Emissions from the stacks of the plant show an enrichment of Mn compared to Fe, with a $\mathrm{Mn} / \mathrm{Fe}$ ratio around 3 (Table 1). At the near-field site, the $\mathrm{Mn} / \mathrm{Fe}$ ratio remained below 1, except for two periods (May 19-21 and May 31-June 1) when both metal concentrations were very low. In addition, the $\mathrm{Mn} / \mathrm{Fe}$ ratio during the two periods under the influence of $\mathrm{NE}$ winds (May 25-27 and June 1-3) was in the range 0.3-0.4. This result, coupled with the increase of potassium from $\mathrm{KCl}$ (steelworks sintering emissions proxy) observed by the HRToF-AMS during the same periods, suggests that the plumes emitted by the Fe-Mn plant were mixed, before reaching the sampling site, with emissions from the adjacent steelworks, for which the $\mathrm{Mn} / \mathrm{Fe}$ ratio is very low $(<0.01)$ (Alleman et al., 2010). Other elemental ratios reported in Table 1 show that values calculated for the near-field site are very different from those determined at the stacks, suggesting that the plumes were quickly (within a few minutes) mixed with pollutants emitted by other sources (e.g. steelworks, truck traffic in the industrial zone) (Mbengue et al., 2017) before reaching the sampling site. This is certainly due to the unstable atmospheric conditions prevailed most of the time during the sampling 
446 campaign (Figure 3d), favoring plumes dispersion. This is especially true during sea breeze 447 events, with the formation of an unstable TIBL, as those unambiguously identified during the 448 May 25-27 period, the longer sea breeze episode of the field campaign.

\section{$449 \quad 4.2 \quad$ Particle size distributions}

450 Figure 8 shows the time series of the particle number size distribution between 10 and 500 $451 \mathrm{~nm}$, along with the average size distribution for the entire study. The average size distribution 452 has a single mode at $40 \mathrm{~nm}$ (in $D_{m}$ ). However, the particle number concentrations and size 453 distributions varied dynamically during the study. Several periods displayed an increase in the 454 particle number concentration. During most of these periods, size distributions were unimodal 455 with a mode centered at 40-60 nm (e.g. May 19, 28, 29, 30, June 1). However, size 456 distributions observed during NE wind periods (May 25-27, June 2) were very different, and 457 showed a mode at much smaller sizes, below $20 \mathrm{~nm}$. This observation was also quite obvious 458 during sea breeze events on May 25-27 (Figure 4d), systematically associated with an 459 increase in particles of small sizes centered at around $20 \mathrm{~nm}$. The presence of this nucleation 460 mode when the sampling site was under the direct influence of metalworking emissions 461 suggests the occurrence of new particle formation events. New particle formation is a 462 phenomenon which has been extensively observed at various urban, remote, and coastal 463 locations (Curtius, 2006; Holmes, 2007; Kulmala et al., 2004; Zhang et al., 2012). Thus, these 464 events may occur in polluted as well as in very clean environments. Usually, when new 465 particle formation and growth events occur at a regional scale, the SMPS data trend line 466 shows a "banana shape". Indeed, an increase of the concentration of very small particles $(<15$ $467 \mathrm{~nm}$ ) is first observed when these new particles are formed. Then, an increase of the mode is 468 observed during the following hours, when gaseous compounds with low volatility condense 
onto the surface of these new particles, or when these particles agglomerate to form bigger 470 ones (Setyan et al., 2014; Setyan et al., 2012). The absence of "banana shapes" and the 471 presence of a constant nucleation mode during several hours in the present SMPS dataset 472 (Figure 4d) suggest that new particle formation was due to continuous emissions from a single 473 point source, located at a constant distance from the near-field sampling site. This may be due 474 to major emissions of these new particles or gaseous precursors from the Fe-Mn plant stacks 475 (or adjacent steelworks emissions), which undergo rapid cooling in the ambient air, thus 476 promoting fast condensation of the gaseous emissions and transformation of stack pipe 477 generated particles, before reaching the sampling site.

478 Another evidence for new particles formation and growth is emphasized by mass size 479 distribution measurements. Figure 7 a shows the mass size distributions determined at the 480 sampling site with the 13-stage impactor. $\mathrm{PM}_{2.5}$ concentrations varied in the range of 11-44 $481 \mu \mathrm{g} \mathrm{m}^{-3}$ during this study. The highest concentrations observed during the whole field 482 campaign were reached when the wind was coming from the NE direction at relatively low 483 speed, which counteracted dilution of the plumes. The total mass was dominated by 484 submicron particles (from 0.1 to $1 \mu \mathrm{m}$ ), which accounted for $63.1 \%$ of the mass, while 485 particles larger than $1 \mu \mathrm{m}$ accounted for $33.5 \%$. Particles in the ultrafine size range $(<0.1 \mu \mathrm{m})$ 486 had a negligible contribution to the mass (3.4\%), even if their number was much higher than 487 particles of larger sizes. The mass size distributions did not fluctuate drastically during the 488 study, except for two periods. Between May 15-17, the mass was dominated by coarse 489 particles $(65 \%$ of the total, with probably a high contribution of sea salts, considering the 490 wind direction and results from ATOFMS and ICP/MS - Figures 5c and 6), while from May 491 29-31, the contribution of submicron particles was higher (77\% of the total mass). 
These size distributions observed at the near-field site were very different to those observed at

493 the stacks of the Fe-Mn plant (Figure 7b). Emissions from the plant were totally dominated by 494 particles in the ultrafine range $(60.1 \%$ of particles $<0.1 \mu \mathrm{m})$, while these particles accounted 495 for only $3.4 \%$ at the near-field site. These observations provide further evidence to support the 496 fast evolution of the plumes and also indicate that emissions from the stacks are likely very 497 quickly diluted in an air mass containing larger particles before reaching the sampling site. In 498 the presence of those larger particles, ultrafine particles freshly emitted at the stacks may 499 quickly agglomerate to form larger particles before reaching the sampling site. In summary, 500 ultrafine particles $\left(D_{m} \sim 20 \mathrm{~nm}\right)$ seem to be continuously generated by Fe-Mn plant and 501 steelworks emissions, but within the plumes fast agglomeration processes could result, in a 502 few minutes, in the formation of larger particles in the accumulation mode $(0.1-1.0 \mu \mathrm{m})$.

\section{$503 \quad 4.3 \quad$ Trace gases}

504 Figure 5f-h shows the time series of several VOC families (aromatics, alkanes, alkenes, 505 oxygenated VOCs, biogenic VOCs). Most of them exhibited high concentrations during the 506 first five days of the campaign (May 15-19), then decreased significantly until the end of the 507 study. However, some short events are also apparent, especially during the NE wind periods, 508 i.e. under the influence of metalworking activities. Benzene was the only VOC to increase 509 significantly when the sampling site was under the influence of emissions from the Fe-Mn 510 plant and steelworks. Toluene also increased during these periods, but to a lesser extent. 511 Toluene and benzene were by far the most concentrated VOCs released from the stacks of the 512 Fe-Mn factory, especially from the stack above the firing area, with a toluene/benzene ratio in

513 the range 2-3. However, during NE wind periods, the toluene/benzene ratio was always $\sim 0.5$ 514 at the sampling site, similar to the ratio previously measured in the same area (Roukos et al., 
2009). This result implies either that emissions from the stacks were already highly processed

516 when the plumes reached the sampling site (as evidenced previously for particles), or that

517 there was another important source of benzene near the Fe-Mn plant (e.g. the steelworks,

518 Ciaparra et al., 2009). Several additional events were identified, such as during the nights of

519 May 22-23, May 23-24, and May 31-June 1, with an increase of short-chain alkanes (Figure

$5205 \mathrm{~g}$ ). These events took place during NW and W wind periods, suggesting that short-chain

521 alkane emissions could possibly be related to petrochemical industrial activities in the area

522 (Figure 1a).

523 On the bottom right of Figure 5, two pie charts show the average VOC composition during

524 NE wind periods (downwind metalworking sources) and measured at the stacks. VOCs

525 emitted at the stacks are totally dominated by aromatic compounds (mainly toluene and

526 benzene), which account for $60 \%$ of the total measured VOCs, while this class of compounds

527 accounts for only $31 \%$ at the sampling site during NE wind periods. These pie charts also

528 show that oxygenated compounds emitted at the stacks represent $7 \%$ of the total VOCs, while

529 at the sampling site, they account for $27 \%$ of the total VOCs. Moreover, none of the

530 oxygenated compounds identified at the sampling site come from aromatic precursors. These

531 results suggest that emissions from the stacks are, during NE wind periods, quickly diluted in

532 an aged air mass before reaching the sampling site. This also confirms previous observations

533 within the same industrial complex (Roukos et al., 2009) that highlighted the fact that even in

534 anthropogenically-influenced areas, long-range transport can have a significant contribution

535 to the observed concentrations of gaseous pollutants.

536 Figure $5 \mathrm{~d}$-e shows the time series of the main trace gases $\left(\mathrm{CO}, \mathrm{CO}_{2}, \mathrm{NO}_{\mathrm{x}}, \mathrm{O}_{3}, \mathrm{SO}_{2}\right)$. Among 537 them, $\mathrm{CO}_{2}$ and $\mathrm{O}_{3}$ were the only gases to show significant diurnal trends. $\mathrm{O}_{3}$ varied between $53820 \mathrm{ppb}$ (nighttime) and $40 \mathrm{ppb}$ (daytime) on average. The average $\mathrm{CO}_{2}$ concentration was 460 
539 ppm during the night and 430 ppm during the day. Its diurnal pattern was mainly driven by

540 boundary layer dynamics. Vegetation and variation in the surface temperature of the sea could 541 also influence the diurnal pattern of $\mathrm{CO}_{2}$. The concentration of the other gases varied 542 dynamically throughout the study. $\mathrm{CO}$ and $\mathrm{SO}_{2}$ increased significantly during $\mathrm{NE}$ wind 543 periods, when the sampling site was under the direct influence of metallurgical emissions.

544 The CO concentration during these periods was in the range 3-10 ppm, 10 times higher than 545 during other periods. The $\mathrm{SO}_{2}$ concentration also increased 10-fold during NE wind periods. 546 Measurements performed at the stacks of the Fe-Mn factory confirmed that the firing area of 547 the sintering unit of the plant emitted very large amounts of these two gases (Table 2). 548 Sulfuric acid is one species commonly involved in particle nucleation, along with water 549 (Holmes, 2007; Zhang et al., 2012). Therefore, the very high amounts of $\mathrm{SO}_{2}$ emitted by this 550 factory, followed by its rapid oxidation to sulfuric acid, could play a major role in the new 551 particle formation events observed at the sampling site downwind of metalworking emissions 552 (Section 4.2). However, for the period of sea breezes during which the sampling site was 553 unambiguously influenced by metalworking plumes (Figure $4 \mathrm{~b}$ and $4 \mathrm{~d}$ ), organics in NR-PM 554 are clearly more abundant than sulfates (Figure 4e). Thus, after the formation of new particles, 555 which have a diameter of a few nm, the growth of these particles up to larger sizes could be 556 more driven by organics than by sulfate formation, or results from fast agglomeration 557 processes with preexisting particles.

558 4.4 Physico-chemical characteristics of plumes influenced by different pollutant sources

560 Considering the atmospheric dynamic from LIDAR and SODAR data (section 3), three short 561 time (30 minutes) but highly specific events were identified, influenced by steelworks and Fe- 
Mn plant activities (from NE-E wind direction), by petrochemical activity (from NW wind

563 direction) and by urban activities (from SE wind direction), respectively. The corresponding 564 gas and particle parameters are listed in Table 2, while Figure 9 shows the average particle number size distributions during these three thirty-minute periods. The particle $\left(\mathrm{PM}_{2.5}\right.$, sum $\mathrm{NR}-\mathrm{PM}_{1}$ and particles number concentrations) and gas $\left(\mathrm{CO}, \mathrm{SO}_{2}\right)$ concentrations were very 567 high in the metalworking emissions. Indeed, the total NR-PM 1 concentration in this plume 568 was $37.7 \mu \mathrm{g} \mathrm{m}^{-3}$, much higher than in the plume from the refinery in the NW $\left(16.2 \mu \mathrm{g} \mathrm{m}^{-3}\right)$ 569 and from the urban traffic in the $\mathrm{S}\left(2.9 \mu \mathrm{g} \mathrm{m}^{-3}\right)$, while the particle number concentration was around 20-30 times higher. In terms of chemical composition, the contributions of nitrate (22.3\%, vs. $12.3 \%$ for petrochemistry and $13.8 \%$ for urban emissions) and non-sea salt chloride $(6.9 \%$, vs. $1.2 \%$ and $3.4 \%)$ were significantly higher, and that of sulfate lower $573(12.7 \%$, vs. $50.0 \%$ and $24.1 \%)$ in the plume from the metallurgy plant and steelworks, 574 compared to the two other plumes. Results obtained with the ATOFMS (Table 2) showed that most metal-containing particles were also mainly coming from the metallurgical area, such as

$576 \mathrm{Fe}$ - and K-rich particles. In addition to these, $\mathrm{Ca}, \mathrm{Pb}$, and other metals-rich particles were also 577 present in much higher concentrations when the near-field site was under the influence of 578 metallurgical emissions. Among the trace gases, $\mathrm{CO}$ and $\mathrm{SO}_{2}$ were significantly higher during 579 the NE-E wind period, compared to other periods, and thus their presence was highly 580 influenced by these industrial activities. The presence of high mixing ratios of $\mathrm{SO}_{2}(47.8 \mathrm{ppb})$, 581 and low contributions of sulfate during the NE-E wind period suggest that chemical 582 processing was not fast enough to totally oxidize $\mathrm{SO}_{2}$ to sulfate over a distance of $<1 \mathrm{~km}$, 583 even if new particle formation events were observed at the sampling site during this NE-E 584 wind period (see Section 4.3). However, considering metal-bearing particles as a proxy for 585 refractory compounds, the latter contribution to particles smaller than $100 \mathrm{~nm}$ is relatively low 
586

587

588

589

590

591

592

\section{Conclusion}

594 The aim of the NANO-INDUS project was to study the evolution of physico-chemical 595 characteristics of fine particles emitted by industrial activities over a short distance, before 596 they reach surrounding populated areas. This was performed in two steps. First, particles 597 emitted by a ferromanganese alloy plant, located in a multi-influenced industrial area, were 598 directly sampled and analyzed. Secondly, a field campaign was undertaken in the near-field of 599 the plant chimneys, in order to determine the concentration, chemical composition, and size 600 distribution of the fine particles emitted in this multifaceted atmospheric environment.

601 Results obtained during the field campaign showed that unstable atmospheric conditions 602 inside the thermal internal boundary layer (TIBL), due to the occurrence of sea breezes, 603 promote entrapment and mix of pollutants (here Fe-Mn plant emissions, mixed with 604 emissions from an adjacent steelworks). These TIBL unstable periods were characterized by a 605 very high mass concentration of fine particles $\left(38 \mu \mathrm{g} \mathrm{m}^{-3} \mathrm{NR}-\mathrm{PM}_{1}\right)$, compared to other 606 periods dominated by urban or marine influences. These results highlight the huge influence 607 of metalworking emissions on ambient air quality and raise questions about occupational 608 exposure of workers. The chemical composition of particles during these sea breeze periods 
609 was also characteristic, as the contribution of metal-rich particles, organics, and nitrates

610 increased significantly, while that of sulfate decreased, compared to other periods. In addition

611 to new particle formation at the stacks of the Fe-Mn plant, particle growth was also observed

612 in the plume from the metallurgical area. In parallel to possible fast agglomeration processes

613 with preexisting particles, the latter phenomenon was mainly driven by the condensation of 614 organics.

615 This work has important implications in terms of air quality monitoring strategies. First, 616 people working in an industrial area may be continuously exposed to fine particle 617 concentrations going well beyond recommendations from Public Health Authorities (e.g. the 618 WHO annual mean guideline value of $10 \mu \mathrm{g} \mathrm{m}^{-3}$ for $\mathrm{PM}_{2.5}$ ). Second, our results show that, 619 even over short distances, the chemical composition and size of these fine particles may 620 evolve rapidly, and that their characteristics at the boundary of an industrial complex may 621 differ from those directly emitted at the stacks, the only position monitored by manufacturers 622 to comply with regulation and develop emission control strategies. Generally speaking, it is 623 therefore suggested, for towns increasingly influenced by such activities, that air quality 624 management plans address these observations, for example by means of special monitoring in 625 neighboring urban zones, dedicated to the apportionment of processed metalworking 626 emissions.

\section{Author contribution}

629 PF, NL, KD, VR, LYA, CS, and JCW designed the study. AS, PF, NL, KD, VR, LYA, and 630 CS organized the field campaign at the Fe-Mn plant. AS, PF, NL, KD, VR, LYA, CS, JA, PA, $631 \mathrm{RMH}, \mathrm{FC}, \mathrm{DD}, \mathrm{PD}, \mathrm{MF}, \mathrm{PG}, \mathrm{TL}, \mathrm{HM}$, and SM participated in the data acquisition during the 
632 field campaign and worked on the data treatment. All the co-authors participated in the

633 interpretation of the results. AS wrote the manuscript, with contributions from PA and MF for

634 the sections on atmospheric dynamics and metalworking plume detection. All the co-authors

635 gave their feedback on the different versions of the manuscript, and approved the final

636 version.

638 Acknowledgements

639 The NANO-INDUS project was funded by the French Environment and Energy Management 640 Agency (ADEME), grant $\mathrm{N}^{\circ}$ 11-81-C0089. IMT Lille Douai, LPCA and PC2A participate in 641 the CaPPA (funded by the ANR through the PIA) and CLIMIBIO projects, both also funded

642 by the "Hauts-de-France" Regional Council and the European Regional Development Fund. $643 \mathrm{HM}$ and JA acknowledge support from the ADEME and the Irish Research Council, 644 respectively. The authors would also like to thank Emmanuel Fiani (ADEME) for fruitful 645 discussions, François Blond (Glencore Manganèse France) for logistic assistance during the 646 field campaign, and Philippe Le Louer (LECES) for the samplings at the chimneys.

648 Declarations of interest

649 None.

$651 \quad$ References

652 Commision Of The European Communities. Vol SEC (2005) 1133. Brussels, 2005.

653 World Health Organization. Air quality guidelines for particulate matter, ozone, nitrogen 654 dioxide and sulfur dioxide - Summary of risk assessment, Geneva (Switzerland), 2006. 
Alleman LY, Lamaison L, Perdrix E, Robache A, Galloo J-C. PM10 metal concentrations and source identification using positive matrix factorization and wind sectoring in a French industrial zone. Atmospheric Research 2010; 96: 612-625.

658 Almeida SM, Lage J, Fernández B, Garcia S, Reis MA, Chaves PC. Chemical 659 characterization of atmospheric particles and source apportionment in the vicinity of a 660 steelmaking industry. Science of The Total Environment 2015; 521-522: 411-420.

661 Amodio M, de Gennaro G, Di Gilio A, Tutino M. Monitoring of the Deposition of PAHs and 662 Metals Produced by a Steel Plant in Taranto (Italy). Advances in Meteorology 2014; 2014: 66310.

664 Arndt J, Deboudt K, Anderson A, Blondel A, Eliet S, Flament P, et al. Scanning electron 665 microscopy-energy dispersive X-ray spectrometry (SEM-EDX) and aerosol time-of-flight 666 mass spectrometry (ATOFMS) single particle analysis of metallurgy plant emissions. 667 Environmental Pollution 2016; 210: 9-17.

668 Augustin P, Delbarre H, Lohou F, Campistron B, Puygrenier V, Cachier H, et al. 669 Investigation of local meteorological events and their relationship with ozone and aerosols 670 during an ESCOMPTE photochemical episode. Ann. Geophys. 2006; 24: 2809-2822.

671 Badol C, Locoge N, Galloo J-C. Using a source-receptor approach to characterise VOC 672 behaviour in a French urban area influenced by industrial emissions: Part II: Source 673 contribution assessment using the Chemical Mass Balance (CMB) model. Science of The 674 Total Environment 2008a; 389: 429-440.

675 Badol C, Locoge N, Léonardis T, Galloo J-C. Using a source-receptor approach to 676 characterise VOC behaviour in a French urban area influenced by industrial emissions Part I: 677 Study area description, data set acquisition and qualitative data analysis of the data set. 678 Science of The Total Environment 2008b; 389: 441-452.

679 Baraniecka J, Pyrzyńska K, Szewczyńska M, Pośniak M, Dobrzyńska E. Emission of 680 polycyclic aromatic hydrocarbons from selected processes in steelworks. Journal of 681 Hazardous Materials 2010; 183: 111-115.

682 Beyrich F. Mixing height estimation from sodar data - A critical discussion. Atmospheric 683 Environment 1997; 31: 3941-3953.

684 Boyouk N, Léon J-F, Delbarre H, Augustin P, Fourmentin M. Impact of sea breeze on vertical 685 structure of aerosol optical properties in Dunkerque, France. Atmospheric Research 2011; 686 101: 902-910.

687 Brook RD, Franklin B, Cascio W, Hong YL, Howard G, Lipsett M, et al. Air pollution and 688 cardiovascular disease - A statement for healthcare professionals from the expert panel on 689 population and prevention science of the American Heart Association. Circulation 2004; 109: $690 \quad 2655-2671$.

691 Canagaratna MR, Jayne JT, Jimenez JL, Allan JD, Alfarra MR, Zhang Q, et al. Chemical and 692 microphysical characterization of ambient aerosols with the Aerodyne aerosol mass 693 spectrometer. Mass Spectrometry Reviews 2007; 26: 185-222.

694 Cazier F, Genevray P, Dewaele D, Nouali H, Verdin A, Ledoux F, et al. Characterisation and 695 seasonal variations of particles in the atmosphere of rural, urban and industrial areas: Organic 696 compounds. Journal of Environmental Sciences 2016; 44: 45-56. 

for black and organic carbon emission inventories. Atmospheric Environment 2011; 45: 54075414.

700 Ciaparra D, Aries E, Booth M-J, Anderson DR, Almeida SM, Harrad S. Characterisation of 701 volatile organic compounds and polycyclic aromatic hydrocarbons in the ambient air of steelworks. Atmospheric Environment 2009; 43: 2070-2079.

Crenn V, Fronval I, Petitprez D, Riffault V. Fine particles sampled at an urban background

704

705

706

707 site and an industrialized coastal site in Northern France - Part 1: Seasonal variations and chemical characterization. Science of The Total Environment 2017; 578: 203-218.

Curtius J. Nucleation of atmospheric aerosol particles. Comptes Rendus Physique 2006; 7: 1027-1045.

Dai Q-L, Bi X-H, Wu J-H, Zhang Y-F, Wang J, Xu H, et al. Characterization and Source Identification of Heavy Metals in Ambient PM10 and PM2.5 in an Integrated Iron and Steel Industry Zone Compared with a Background Site. Aerosol and Air Quality Research 2015; 15: 875-887.

Dall'Osto M, Booth MJ, Smith W, Fisher R, Harrison RM. A Study of the Size Distributions and the Chemical Characterization of Airborne Particles in the Vicinity of a Large Integrated Steelworks. Aerosol Science and Technology 2008; 42: 981-991.

de Gouw J, Warneke C. Measurements of volatile organic compounds in the earths atmosphere using proton-transfer-reaction mass spectrometry. Mass Spectrometry Reviews 2007; 26: 223-257.

DeCarlo PF, Kimmel JR, Trimborn A, Northway MJ, Jayne JT, Aiken AC, et al. Fielddeployable, high-resolution, time-of-flight aerosol mass spectrometer. Analytical Chemistry 2006; 78: 8281-8289.

Detournay A, Sauvage S, Locoge N, Gaudion V, Leonardis T, Fronval I, et al. Development of a sampling method for the simultaneous monitoring of straight-chain alkanes, straightchain saturated carbonyl compounds and monoterpenes in remote areas. Journal of Environmental Monitoring 2011; 13: 983-990.

DREAL. L'industrie au regard de l'environnement en Nord - Pas-de-Calais - Les chiffres clés, 2011.

Flament P, Mattielli N, Aimoz L, Choël M, Deboudt K, Jong Jd, et al. Iron isotopic fractionation in industrial emissions and urban aerosols. Chemosphere 2008; 73: 1793-1798.

Fraser MP, Yue ZW, Tropp RJ, Kohl SD, Chow JC. Molecular composition of organic fine particulate matter in Houston, TX. Atmospheric Environment 2002; 36: 5751-5758.

Gard E, Mayer JE, Morrical BD, Dienes T, Fergenson DP, Prather KA. Real-Time Analysis of Individual Atmospheric Aerosol Particles: Design and Performance of a Portable ATOFMS. Analytical Chemistry 1997; 69: 4083-4091.

Gross DS, Atlas R, Rzeszotarski J, Turetsky E, Christensen J, Benzaid S, et al. Environmental chemistry through intelligent atmospheric data analysis. Environmental Modelling \& Software 2010; 25: 760-769. 
Healy RM, Hellebust S, Kourtchev I, Allanic A, O'Connor IP, Bell JM, et al. Source apportionment of PM2.5 in Cork Harbour, Ireland using a combination of single particle mass spectrometry and quantitative semi-continuous measurements. Atmospheric Chemistry and

740 Physics 2010; 10: 9593-9613.

741 Healy RM, O'Connor IP, Hellebust S, Allanic A, Sodeau JR, Wenger JC. Characterisation of single particles from in-port ship emissions. Atmospheric Environment 2009; 43: 6408-6414.

Hleis D, Fernandez-Olmo I, Ledoux F, Kfoury A, Courcot L, Desmonts T, et al. Chemical profile identification of fugitive and confined particle emissions from an integrated iron and steelmaking plant. Journal of Hazardous Materials 2013; 250-251: 246-255.

Holmes NS. A review of particle formation events and growth in the atmosphere in the various environments and discussion of mechanistic implications. Atmospheric Environment $748 \quad 2007 ; 41: 2183-2201$.

Ji Z, Gan M, Fan X, Chen X, Li Q, Lv W, et al. Characteristics of PM2.5 from iron ore sintering process: Influences of raw materials and controlling methods. Journal of Cleaner Production 2017; 148: 12-22.

Katsoyiannis A, Sweetman AJ, Jones KC. PAH Molecular Diagnostic Ratios Applied to Atmospheric Sources: A Critical Evaluation Using Two Decades of Source Inventory and Air Concentration Data from the UK. Environmental Science \& Technology 2011; 45: 88978906.

756 Kelly FJ, Fussell JC. Air pollution and airway disease. Clinical \& Experimental Allergy 2011; 757 41: 1059-1071.

758 Kfoury A, Ledoux F, Roche C, Delmaire G, Roussel G, Courcot D. PM2.5 source 759 apportionment in a French urban coastal site under steelworks emission influences using constrained non-negative matrix factorization receptor model. Journal of Environmental Sciences 2016; 40: 114-128.

Kulmala M, Vehkamaki H, Petaja T, Dal Maso M, Lauri A, Kerminen VM, et al. Formation and growth rates of ultrafine atmospheric particles: a review of observations. Journal of Aerosol Science 2004; 35: 143-176.

Landkocz Y, Ledoux F, André V, Cazier F, Genevray P, Dewaele D, et al. Fine and ultrafine atmospheric particulate matter at a multi-influenced urban site: Physicochemical characterization, mutagenicity and cytotoxicity. Environmental Pollution 2017; 221: 130-140.

771 Li W, Peng Y, Bai Z. Distributions and sources of n-alkanes in PM2.5 at urban, industrial and 772 coastal sites in Tianjin, China. Journal of Environmental Sciences 2010; 22: 1551-1557.

773 Lin C, Liou N, Chang P-E, Yang J-C, Sun E. Fugitive Coke Oven Gas Emission Profile by 774 Continuous Line Averaged Open-Path Fourier Transform Infrared Monitoring. Journal of the 775 Air \& Waste Management Association 2007; 57: 472-479.

776 Lindinger W, Hansel A, Jordan A. On-line monitoring of volatile organic compounds at pptv 777 levels by means of proton-transfer-reaction mass spectrometry (PTR-MS) - Medical 
applications, food control and environmental research. International Journal of Mass Spectrometry 1998; 173: 191-241.

Marris H, Deboudt K, Augustin P, Flament P, Blond F, Fiani E, et al. Fast changes in chemical composition and size distribution of fine particles during the near-field transport of industrial plumes. Science of The Total Environment 2012; 427-428: 126-138.

Marris H, Deboudt K, Flament P, Grobéty B, Gieré R. Fe and Mn Oxidation States by TEMEELS in Fine-Particle Emissions from a Fe-Mn Alloy Making Plant. Environmental Science \& Technology 2013; 47: 10832-10840.

786

787

788

789

790

791

792

793

794

795

796

797

798

799

800

801

802

803

804

805

806

807

808

809

810

811

812

813

814

815

816

Mbengue S, Alleman LY, Flament P. Size-distributed metallic elements in submicronic and ultrafine atmospheric particles from urban and industrial areas in northern France. Atmospheric Research 2014; 135-136: 35-47.

Mbengue S, Alleman LY, Flament P. Bioaccessibility of trace elements in fine and ultrafine atmospheric particles in an industrial environment. Environmental Geochemistry and Health 2015; 37: 875-889.

Mbengue S, Alleman LY, Flament P. Metal-bearing fine particle sources in a coastal industrialized environment. Atmospheric Research 2017; 183: 202-211.

Oberdörster G. Pulmonary effects of inhaled ultrafine particles. International Archives of Occupational and Environmental Health 2000; 74: 1-8.

Peng C, Zhang F, Guo Z. Separation and Recovery of Potassium Chloride from Sintering Dust of Ironmaking Works. ISIJ International 2009; 49: 735-742.

Pope CA, Burnett RT, Turner MC, Cohen A, Krewski D, Jerrett M, et al. Lung Cancer and Cardiovascular Disease Mortality Associated with Ambient Air Pollution and Cigarette Smoke: Shape of the Exposure-Response Relationships. Environmental Health Perspectives 2011; 119: 1616-1621.

Riffault V, Arndt J, Marris H, Mbengue S, Setyan A, Alleman LY, et al. Fine and ultrafine particles in the vicinity of industrial activities: A review. Critical Reviews in Environmental Science and Technology 2015; 45: 2305-2356.

Roukos J, Locoge N, Sacco P, Plaisance H. Radial diffusive samplers for determination of 8-h concentration of BTEX, acetone, ethanol and ozone in ambient air during a sea breeze event. Atmospheric Environment 2011; 45: 755-763.

Roukos J, Riffault V, Locoge N, Plaisance H. VOC in an urban and industrial harbor on the French North Sea coast during two contrasted meteorological situations. Environmental Pollution 2009; 157: 3001-3009.

Sanderson P, Delgado-Saborit JM, Harrison RM. A review of chemical and physical characterisation of atmospheric metallic nanoparticles. Atmospheric Environment 2014; 94 : 353-365.

Santos G, Fernández-Olmo I, Irabien Á, Ledoux F, Courcot D. Estimating airborne heavy metal concentrations in Dunkerque (northern France). Arabian Journal of Geosciences 2016; 9: 231 . 
Setyan A, Patrick M, Wang J. Very low emissions of airborne particulate pollutants measured from two municipal solid waste incineration plants in Switzerland. Atmospheric Environment 819 2017; 166: 99-109.

820 Setyan A, Song C, Merkel M, Knighton WB, Onasch TB, Canagaratna MR, et al. Chemistry 821 of new particle growth in mixed urban and biogenic emissions - insights from CARES. 822 Atmospheric Chemistry and Physics 2014; 14: 6477-6494.

823

824

825

826

827

828

829

830

831

832

833

834

835

836

837

838

839

840

841

842

843

844

845

846

847

848

849

850

851

852

853

854

855

856

Setyan A, Zhang Q, Merkel M, Knighton WB, Sun Y, Song C, et al. Characterization of submicron particles influenced by mixed biogenic and anthropogenic emissions using highresolution aerosol mass spectrometry: results from CARES. Atmospheric Chemistry and Physics 2012; 12: 8131-8156.

Stull RB. An Introduction to Boundary Layer Meteorology: Kluwer Academic Publishers, 1988.

Taiwo AM, Harrison RM, Shi Z. A review of receptor modelling of industrially emitted particulate matter. Atmospheric Environment 2014; 97: 109-120.

Talbot C, Augustin P, Leroy C, Willart V, Delbarre H, Khomenko G. Impact of a sea breeze on the boundary-layer dynamics and the atmospheric stratification in a coastal area of the North Sea. Boundary-Layer Meteorology 2007; 125: 133-154.

Weingartner E, Saathoff H, Schnaiter M, Streit N, Bitnar B, Baltensperger U. Absorption of light by soot particles: determination of the absorption coefficient by means of aethalometers. Journal of Aerosol Science 2003; 34: 1445-1463.

Weitkamp EA, Lipsky EM, Pancras PJ, Ondov JM, Polidori A, Turpin BJ, et al. Fine particle emission profile for a large coke production facility based on highly time-resolved fence line measurements. Atmospheric Environment 2005; 39: 6719-6733.

Wong HKT, Banic CM, Robert S, Nejedly Z, Campbell JL. In-stack and in-plume characterization of particulate metals emitted from a copper smelter. GeochemistryExploration Environment Analysis 2006; 6: 131-137.

Wu Y, Ge X, Wang J, Shen Y, Ye Z, Ge S, et al. Responses of secondary aerosols to relative humidity and photochemical activities in an industrialized environment during late winter. Atmospheric Environment 2018; 193: 66-78.

Xiang Y, Delbarre H, Sauvage S, Léonardis T, Fourmentin M, Augustin P, et al. Development of a methodology examining the behaviours of VOCs source apportionment with micro-meteorology analysis in an urban and industrial area. Environmental Pollution 2012; 162: 15-28.

Yang Z, Tang S, Zhang Z, Liu C, Ge X. Characterization of PM10 surrounding a cement plant with integrated facilities for co-processing of hazardous wastes. Journal of Cleaner Production 2018; 186: 831-839.

Zhang R, Khalizov A, Wang L, Hu M, Xu W. Nucleation and Growth of Nanoparticles in the Atmosphere. Chemical Reviews 2012; 112: 1957-2011. 
857 Table 1. List of selected elemental ratios for the stacks and the sampling site (data from 858 ICP/MS and ICP/AES analyses).

\begin{tabular}{|c|c|c|c|c|c|c|c|c|c|}
\hline & $\mathrm{Mn} / \mathrm{Fe}$ & $\mathrm{Mn} / \mathrm{Al}$ & $\mathrm{Fe} / \mathrm{Ca}$ & $\mathrm{Na} / \mathrm{Mg}$ & $\mathrm{V} / \mathrm{Ni}$ & $\mathrm{Zn} / \mathrm{Pb}$ & $\mathrm{Cu} / \mathrm{Sb}$ & $\mathrm{Pb} / \mathrm{Cd}$ \\
\hline \multirow{3}{*}{$\mid \begin{array}{l}\frac{v}{\tilde{U}} \\
\frac{\tilde{J}}{\tilde{L}}\end{array}$} & Firing area $(\mathrm{A})$ & 2.62 & 2.99 & 0.91 & $<\mathrm{DL}$ & 0.34 & 0.07 & 12.2 & 15.0 \\
\hline & Cooling area (B) & 3.34 & 3.59 & 4.19 & $<\mathrm{DL}$ & 0.53 & 0.51 & 70.0 & 21.3 \\
\hline & Smelting unit (C) & 0.46 & 1.25 & 2.86 & 2.47 & 0.00 & 11.9 & $<\mathrm{DL}$ & 46.3 \\
\hline \multirow{17}{*}{ 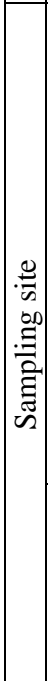 } & $15-17 / 5$ & 0.67 & 0.86 & 0.70 & 2.23 & 0.62 & 1.03 & 10.2 & 36.6 \\
\hline & $17-19 / 5$ & 0.26 & 0.34 & 1.07 & 0.43 & 0.19 & 5.56 & 10.4 & 31.3 \\
\hline & $19-21 / 5$ & 1.90 & 1.29 & 1.43 & 1.09 & 0.88 & 2.32 & 15.8 & 13.5 \\
\hline & $21-23 / 5$ & 0.59 & 0.24 & 0.61 & 1.92 & 1.01 & 2.00 & 3.15 & 35.7 \\
\hline & $23-25 / 5$ & 0.58 & 0.75 & 0.92 & 5.18 & 1.17 & 2.31 & 8.77 & 29.8 \\
\hline & $25-27 / 5$ & 0.30 & 1.51 & 1.86 & 2.17 & 1.08 & 3.19 & 11.1 & 19.5 \\
\hline & $27-29 / 5$ & 0.28 & 0.66 & 1.61 & 6.27 & 1.20 & 2.83 & 7.21 & 26.3 \\
\hline & $29-31 / 5$ & 0.73 & 0.43 & 0.43 & 0.35 & 1.12 & 1.52 & 3.55 & 37.7 \\
\hline & $31 / 5-1 / 6$ & 1.19 & 0.55 & 0.46 & 0.81 & 0.72 & 3.61 & 3.19 & 31.6 \\
\hline & $1-3 / 6$ & 0.39 & 1.29 & 1.48 & 3.43 & 0.79 & 3.48 & 13.2 & 42.2 \\
\hline & $3-5 / 6$ & 0.45 & 0.30 & 1.00 & 0.85 & 0.45 & 2.11 & 7.62 & 56.4 \\
\hline & $5-6 / 6$ & 0.96 & 0.07 & 0.34 & 0.00 & 0.05 & 4.74 & 2.61 & 15.7 \\
\hline & Average & 0.69 & 0.69 & 0.99 & 2.06 & 0.77 & 2.89 & 8.06 & 31.4 \\
\hline & Std dev & 0.47 & 0.46 & 0.51 & 1.98 & 0.38 & 1.31 & 4.31 & 11.9 \\
\hline & Median & 0.59 & 0.61 & 0.96 & 1.51 & 0.84 & 2.58 & 8.20 & 31.5 \\
\hline & Min & 0.26 & 0.07 & 0.34 & 0.00 & 0.05 & 1.03 & 2.61 & 13.5 \\
\hline & Max & 1.90 & 1.51 & 1.86 & 6.27 & 1.20 & 5.56 & 15.8 & 56.4 \\
\hline
\end{tabular}


Table 2. Summary of meteorological conditions and concentrations of particle- and gas-phase data during specific plumes reaching the sampling site and identified with the LIDAR and 862 SODAR.

\begin{tabular}{|c|c|c|c|c|}
\hline & Wind direction & NE-E & NW & SE \\
\hline & Plumes & $\begin{array}{l}\text { Steelworks } \\
\text { Fe-Mn plant }\end{array}$ & Petrochemistry & Urban \\
\hline & Date & $26 / 05 / 2012$ & $03 / 06 / 2012$ & $07 / 06 / 2012$ \\
\hline & Start time (UTC) & $10: 15 \mathrm{am}$ & $11: 30 \mathrm{am}$ & $5: 30 \mathrm{am}$ \\
\hline & End time (UTC) & $10: 45 \mathrm{am}$ & $12: 00 \mathrm{pm}$ & 6:00 am \\
\hline \multirow{3}{*}{ Weather station } & Temperature $\left[{ }^{\circ} \mathrm{C}\right]$ & 21.3 & 11.8 & 15.6 \\
\hline & Relative humidity [\%] & 55 & 94 & 87 \\
\hline & Solar radiation $\left[\mathrm{W} \mathrm{m}^{-2}\right]$ & 801 & 51 & 90 \\
\hline \multirow{2}{*}{ Sonic anemometer } & Wind speed $\left[\mathrm{m} \mathrm{s}^{-1}\right]$ & 4.4 & 2.8 & 3.4 \\
\hline & Atmosphere & unstable & very unstable & unstable \\
\hline Beta Gauge & $\mathrm{PM}_{2.5}\left[\mu \mathrm{g} \mathrm{m}^{-3}\right]$ & 65.7 & N/A & 4.5 \\
\hline SMPS & Particle number $\left[\# / \mathrm{cm}^{3}\right]$ & $154 ’ 847$ & 5,809 & 7’446 \\
\hline \multirow{6}{*}{ HR-ToF-AMS } & $\operatorname{Org}\left[\mu \mathrm{g} \mathrm{m}^{-3}\right]$ & 16.8 & 2.4 & 1.3 \\
\hline & $\mathrm{SO}_{4}^{2-}\left[\mu \mathrm{g} \mathrm{m}^{-3}\right]$ & 4.8 & 8.1 & 0.7 \\
\hline & $\mathrm{NO}_{3}^{-}\left[\mu \mathrm{g} \mathrm{m}^{-3}\right]$ & 8.4 & 2.0 & 0.4 \\
\hline & $\mathrm{NH}_{4}^{+}\left[\mu \mathrm{g} \mathrm{m}^{-3}\right]$ & 5.1 & 3.5 & 0.4 \\
\hline & $\mathrm{Cl}^{-}\left[\mu \mathrm{g} \mathrm{m}^{-3}\right]$ & 2.6 & 0.2 & 0.1 \\
\hline & Sum NR-PM ${ }_{1}\left[\mu \mathrm{g} \mathrm{m}^{-3}\right]$ & 37.7 & 16.2 & 2.9 \\
\hline Aethalometer & $\mathrm{BC}\left[\mu \mathrm{g} \mathrm{m}^{-3}\right]$ & 1.3 & 0.4 & 1.0 \\
\hline \multirow{10}{*}{ ATOFMS } & Na-rich [count $\left.\mathrm{hr}^{-1}\right]$ & 27 & 44 & 224 \\
\hline & K-rich $\left[\right.$ count $\left.\mathrm{hr}^{-1}\right]$ & 275 & 89 & 31 \\
\hline & $\mathrm{EC}\left[\right.$ count $\left.\mathrm{hr}^{-1}\right]$ & 75 & 274 & 35 \\
\hline & $\mathrm{OC} \& \mathrm{PAH}\left[\right.$ count $\left.\mathrm{hr}^{-1}\right]$ & 6 & 8 & 8 \\
\hline & Fe-rich [ count $\left.\mathrm{hr}^{-1}\right]$ & 67 & 58 & 8 \\
\hline & Ca-rich $\left[\right.$ count $\left.\mathrm{hr}^{-1}\right]$ & 25 & 13 & 10 \\
\hline & Mn-rich [ count $\mathrm{hr}^{-1}$ ] & 10 & 11 & 5 \\
\hline & $\mathrm{Pb}$-rich [count $\left.\mathrm{hr}^{-1}\right]$ & 23 & 14 & 0 \\
\hline & V-rich [count $\left.\mathrm{hr}^{-1}\right]$ & 2 & 3 & 0 \\
\hline & Others [count $\mathrm{hr}^{-1}$ ] & 220 & 6 & 12 \\
\hline \multirow{5}{*}{$\begin{array}{l}\text { VOCs cartridges, } \\
\text { TD-GC/MS }\end{array}$} & Biogenic VOCs $\left[\mu \mathrm{g} \mathrm{m}^{-3}\right]$ & 1.8 & 0.8 & 0.6 \\
\hline & Aromatics $\left[\mu^{-3} \mathrm{~m}^{-3}\right]$ & 9.1 & 5.7 & 1.5 \\
\hline & Alkanes $\left[\mu \mathrm{g} \mathrm{m}^{-3}\right]$ & 7.7 & 17.7 & 2.0 \\
\hline & Alkenes $\left[\mu \mathrm{g} \mathrm{m}^{-3}\right]$ & 8.7 & 3.2 & 2.5 \\
\hline & Oxygenated VOCs $\left[\mu \mathrm{g} \mathrm{m}^{-3}\right]$ & 11.5 & 6.2 & 3.9 \\
\hline \multirow{4}{*}{ Gas analyzers } & CO [ppb] & 4666 & 363 & 692 \\
\hline & $\mathrm{NO}_{\mathrm{x}}[\mathrm{ppb}]$ & N/A & 15.7 & 12.8 \\
\hline & $\mathrm{O}_{3}[\mathrm{ppb}]$ & 17.6 & 16.7 & 7.2 \\
\hline & $\mathrm{SO}_{2}[\mathrm{ppb}]$ & 47.8 & N/A & 6.6 \\
\hline
\end{tabular}


864

865

866

867

868

869

Figure 1. (a) Map of the industrial area near Grande-Synthe, with the locations of the sampling site, the emission chimneys of the ferromanganese alloy manufacturing plant, and other industries. (b) Enlarged map showing the location of the LIDAR, with the four directions scanned by the instrument every 15 minutes. (c) Wind rose plot for the entire campaign. Key: $\mathrm{C}$ chemical plant; $\mathrm{G}$ glass manufacturing factory; $\mathrm{M}$ metallurgy; $\mathrm{P}$ plastic manufacturing plant; PC petrochemistry; PP power plant; S steelworks.
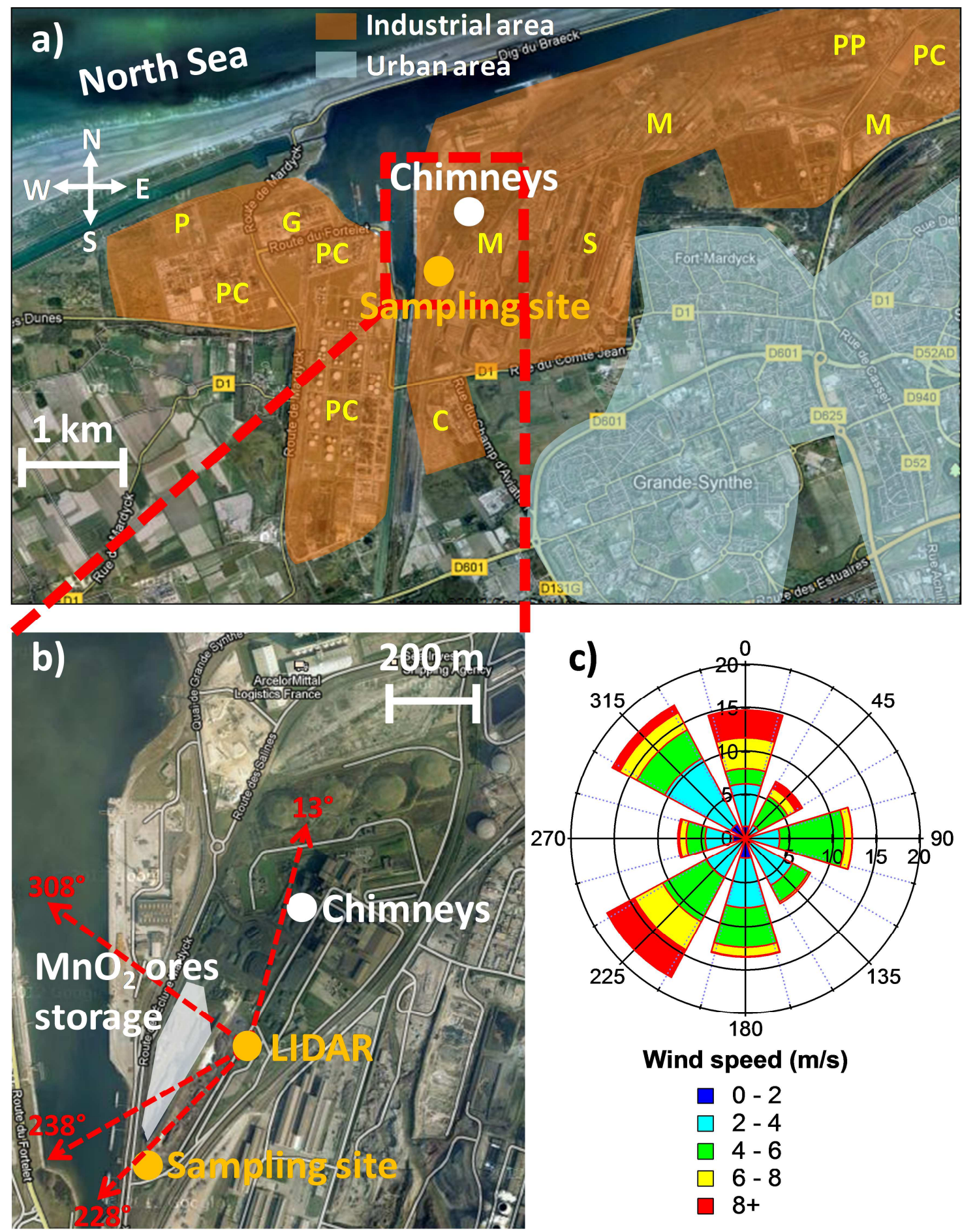

Wind speed $(\mathrm{m} / \mathrm{s})$

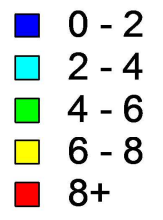


872 Figure 2. Schematic drawing of the ferromanganese alloy manufacturing process and the 873 filtration system used for each stack.

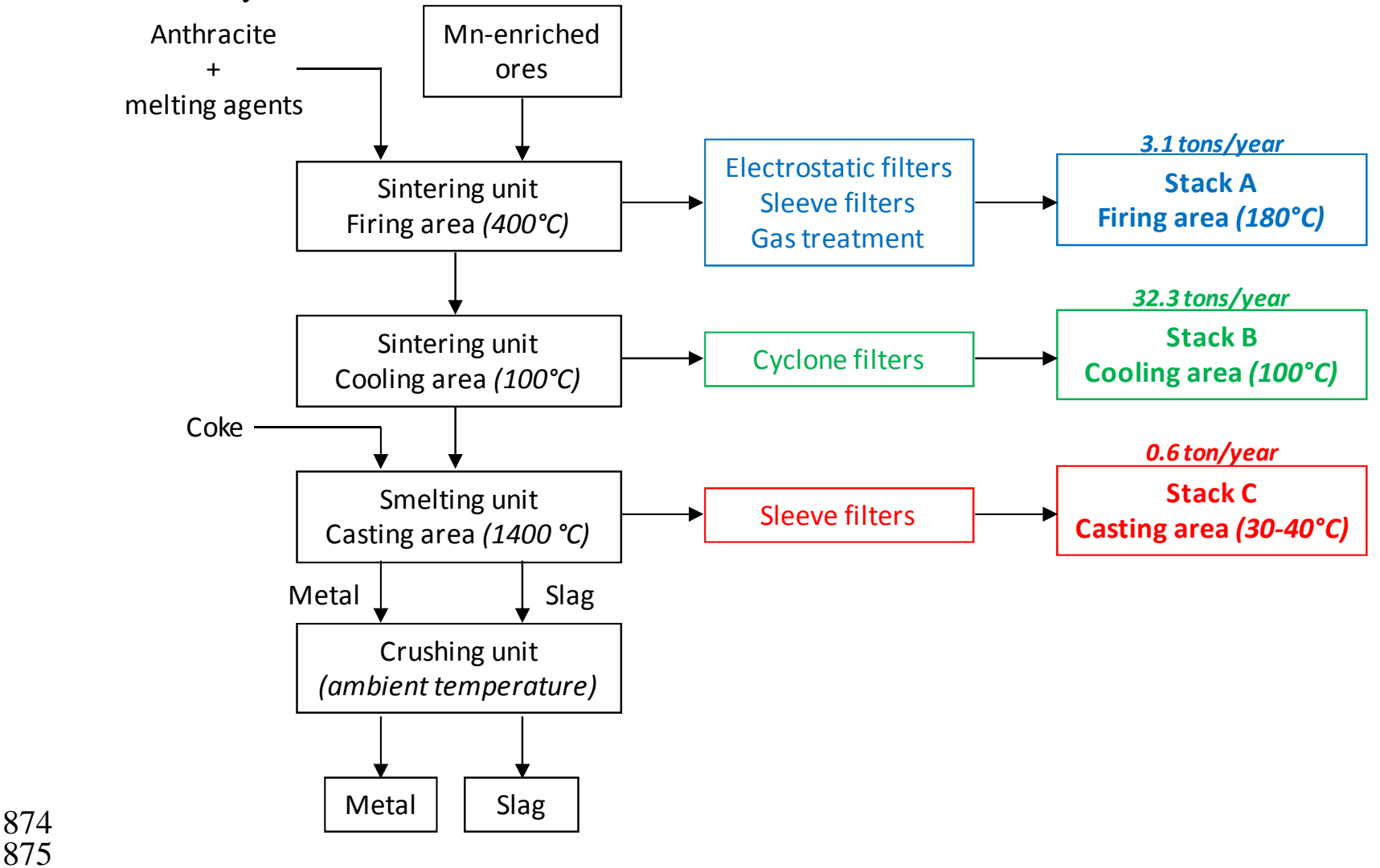


876 Figure 3: Time series of (a) temperature and relative humidity, (b) solar radiation and rain, (c) 877 wind direction colored by wind speed, and (d) atmospheric stability.

NE wind (from chimneys)
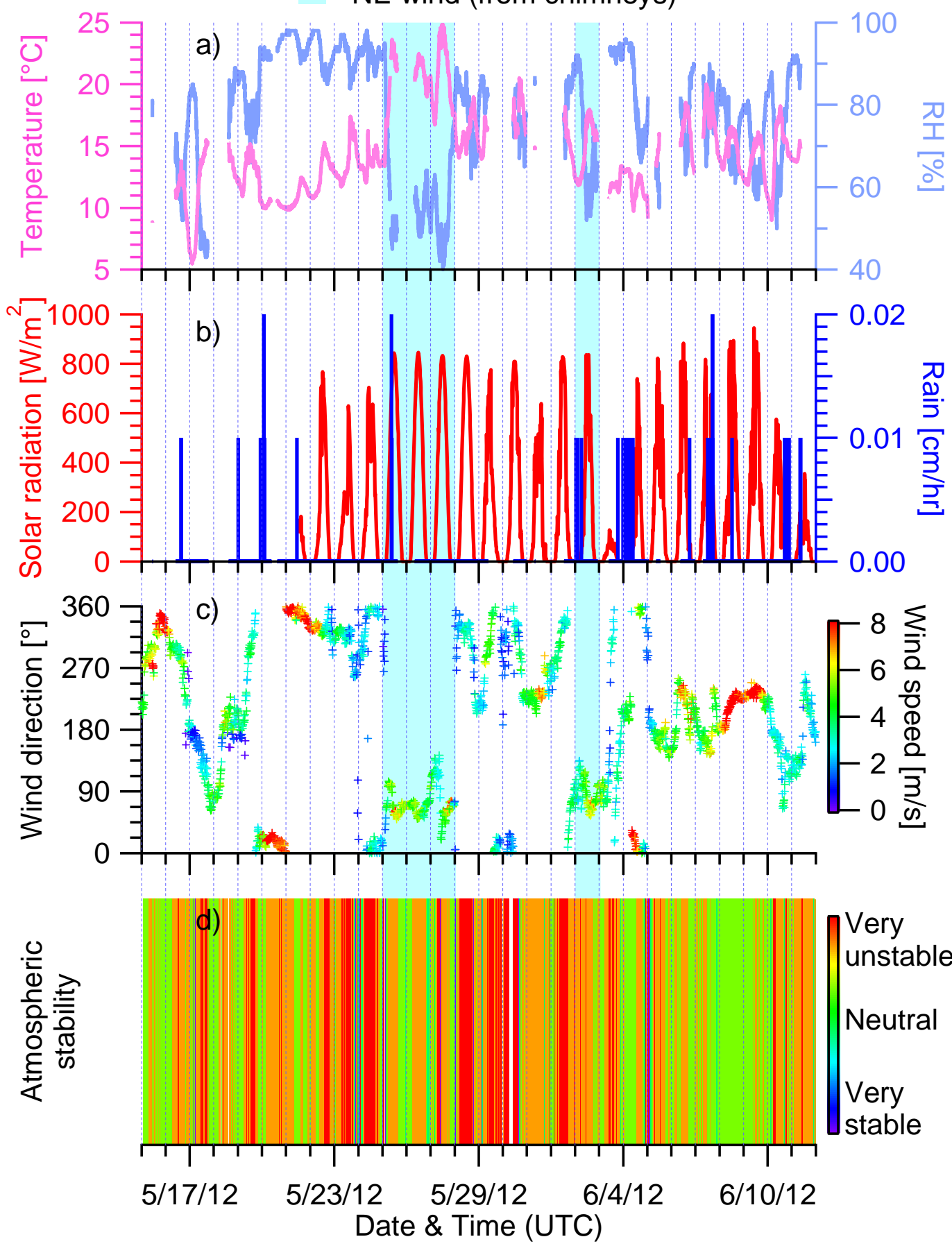
Figure 4. (a) Time-height section of wind direction and wind speed (from SODAR). (b) Time-distance section of the depolarization ratio of LIDAR at $355 \mathrm{~nm}$ when the instrument was pointed towards the near-field sampling site (azimuth angle $228^{\circ}$ in Figure $1 \mathrm{~b}$ ). Time series of (c) $\mathrm{PM}_{2.5}$ (from beta gauge), (d) particle number size distribution (from SMPS), (e) ammonium, chloride (from AMS), and BC (from Aethalometer), (f) organics, sulfate, and nitrate (from AMS) between May $25^{\text {th }}$ and May $27^{\text {th }}, 2012$. The three sea breeze periods are 886 shown on the top of the graph.

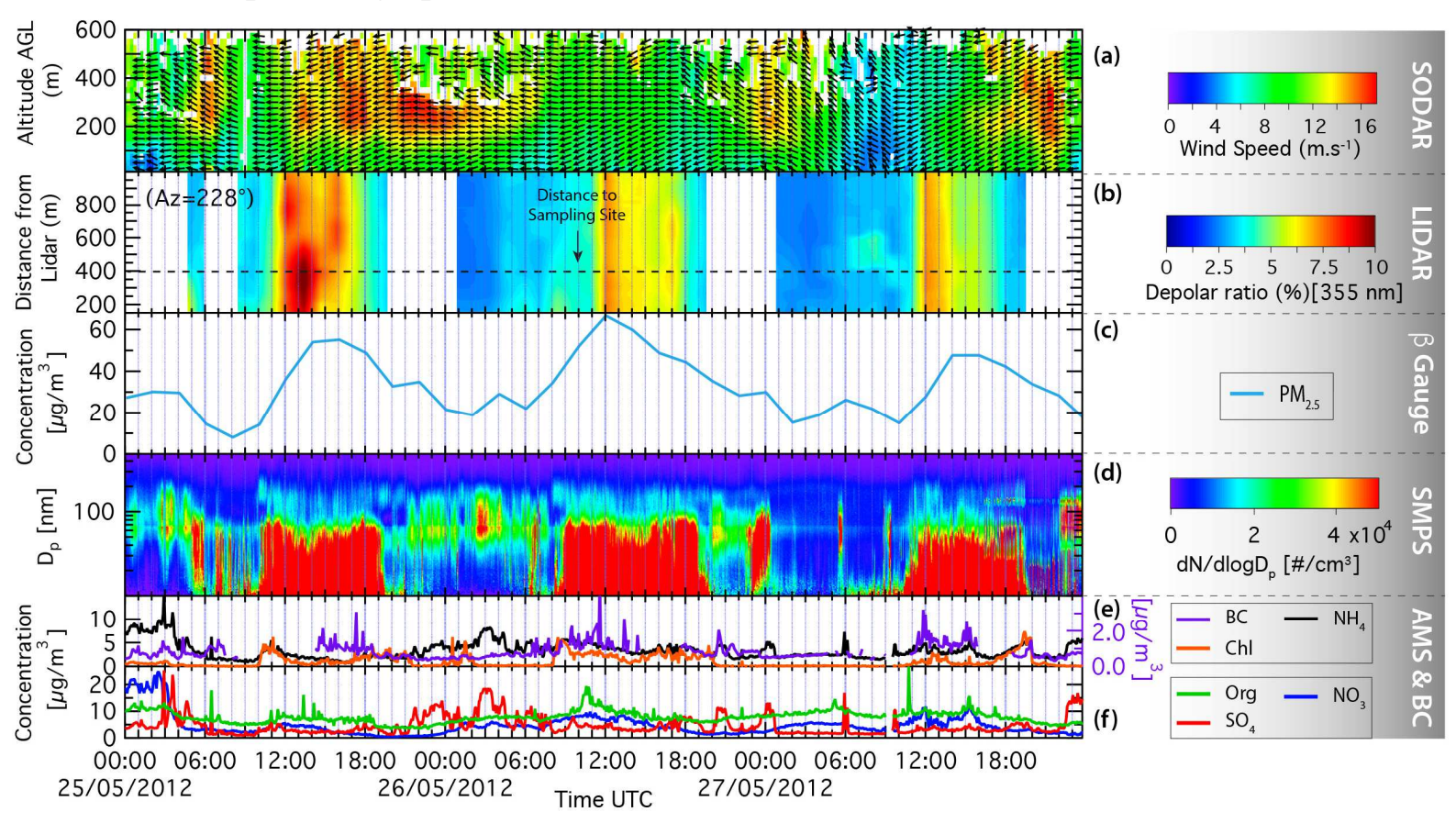


Figure 5. Time series of (a) the daily average wind direction (with length of arrows proportional to the wind speed), (b) chemical species measured by the AMS, the Aethalometer, and (c) the ATOFMS, (d) $\mathrm{CO}, \mathrm{CO}_{2}$, and $\mathrm{NO}_{x}$, (e) $\mathrm{O}_{3}$ and $\mathrm{SO}_{2}$, (f) benzene and toluene, (g) alkanes and alkenes, (h) biogenic and oxygenated VOCs. Shaded regions correspond to NE wind periods (from stacks). The pie charts show the average contribution of

894 the species to the total $\mathrm{PM}_{1}$ mass and VOCs.

NE wind (from chimneys)

$$
\text { 을 을 }
$$

a)

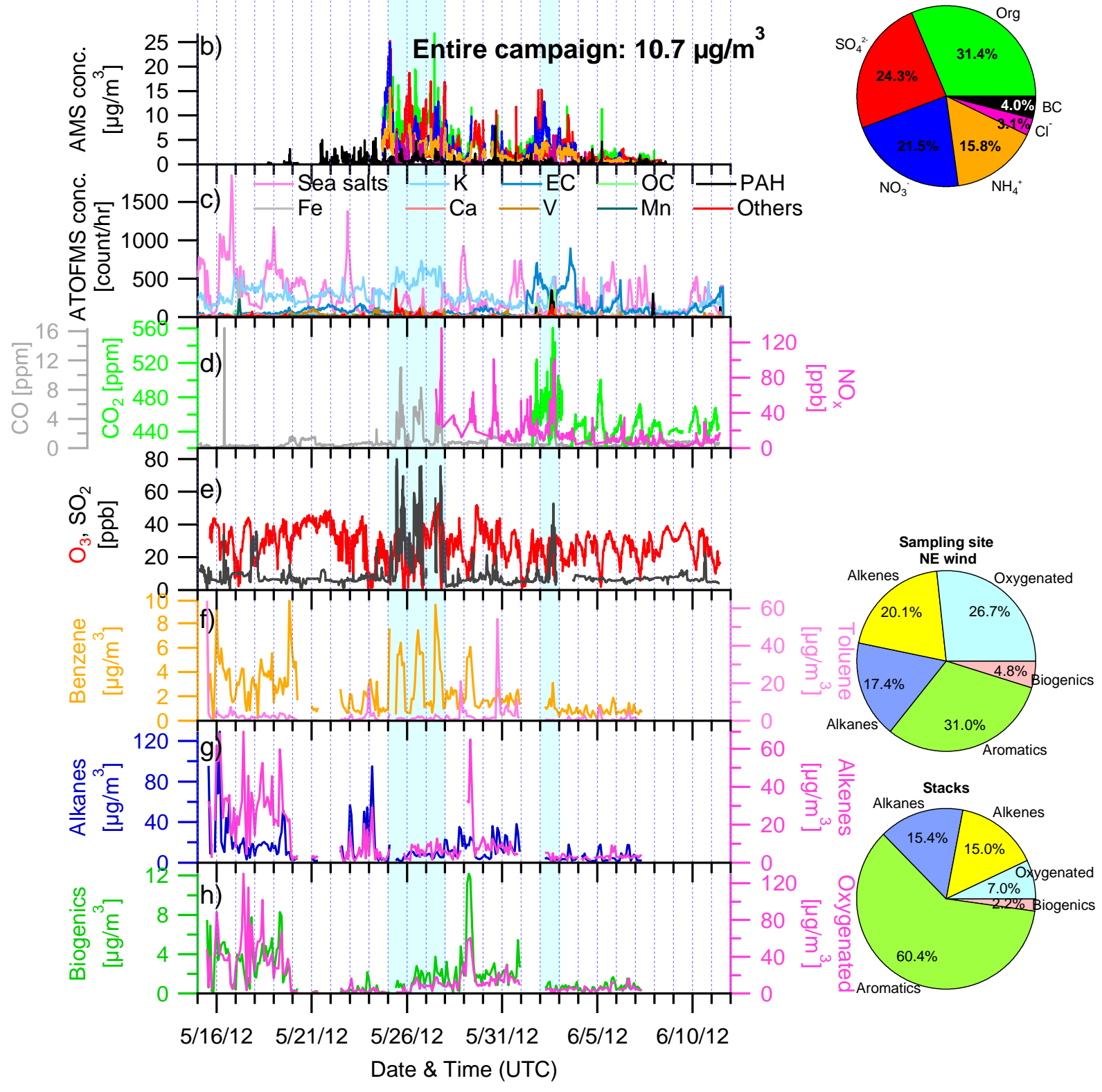


897 Figure 6. Time series of the size-resolved elemental composition (data from ICP/MS and 898 ICP/AES analyses of Teflon filters), along with the average wind direction (length of arrows 899 are proportional to wind speed).

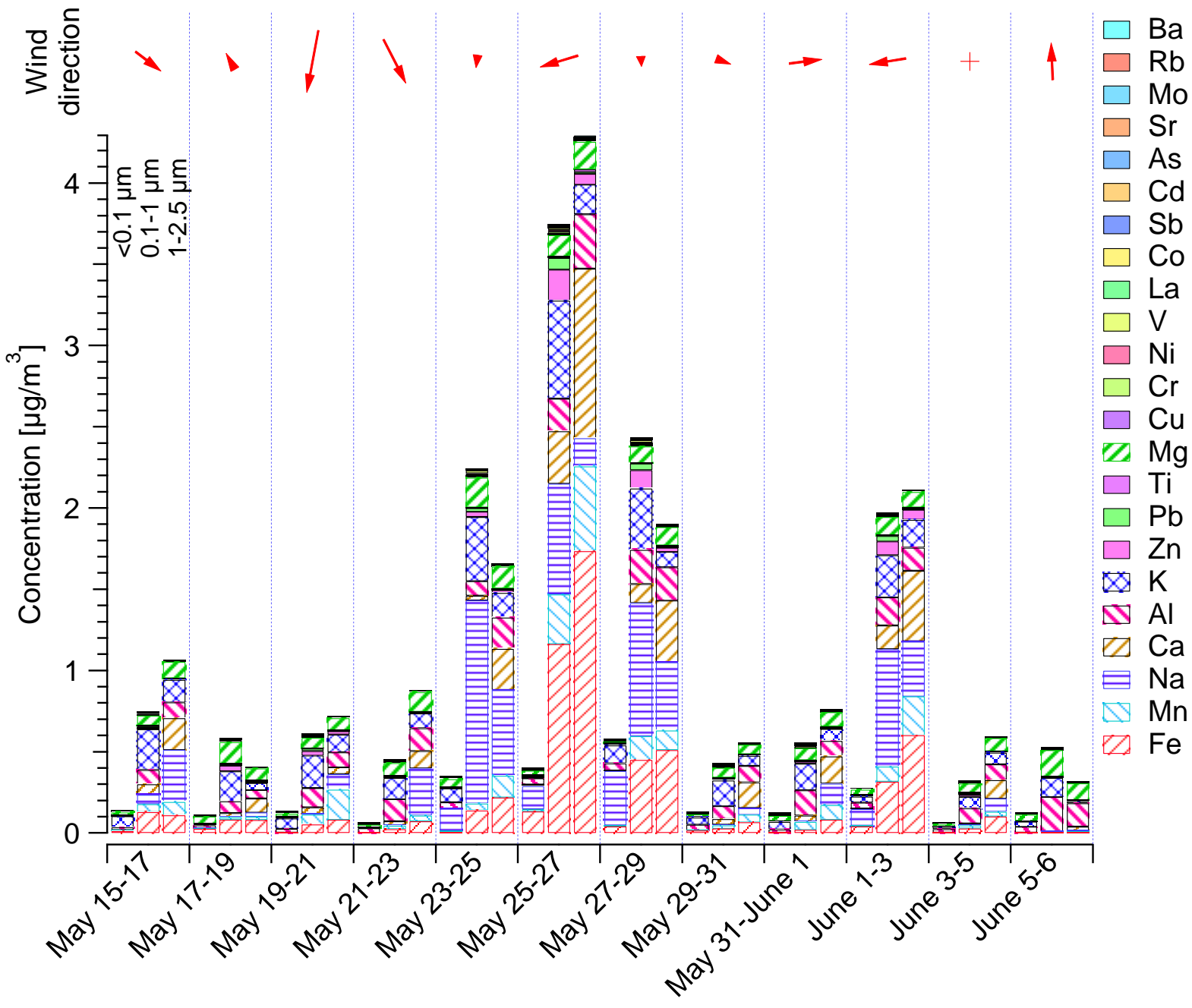


Figure 7. (a) Time series of mass size distributions at the near-field sampling site and average wind directions, and (b) average mass size distributions at the stacks of the ferromanganese alloy manufacturing plant (gravimetrically determined from 13-stage impactor filters). Sizes 905 of arrows are proportional to the wind speed.

a)
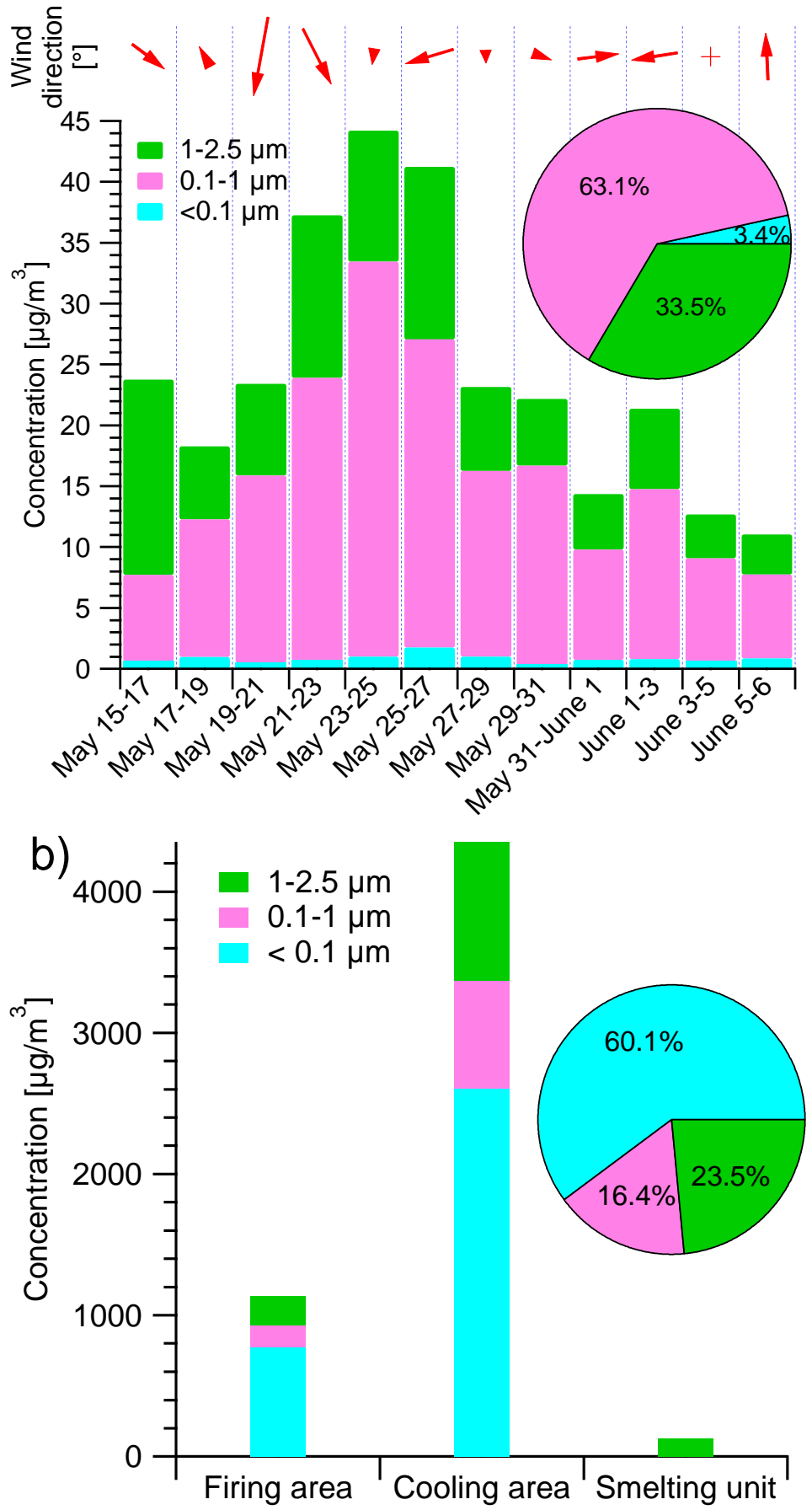
Figure 8. Time series of (a) the daily averaged wind direction (with length of arrows proportional to wind speed) and (b) the particle number size distribution. (c) Average size 910 distributions for the entire campaign and during periods of steelworks $+\mathrm{Fe}-\mathrm{Mn}$ plant, 911 petrochemistry and urban influences (details of the periods in Table 2) (data from the SMPS).
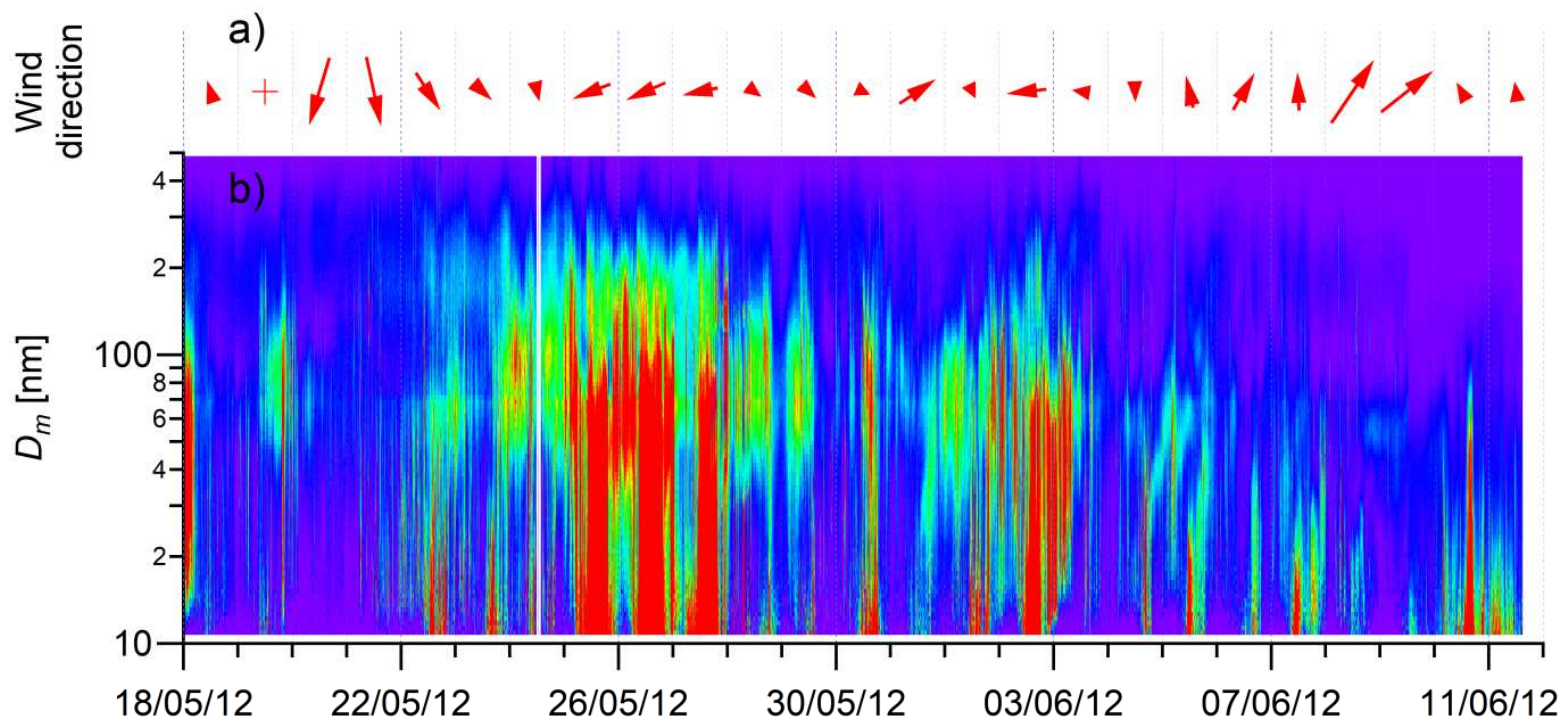

c)

Date \& Time (UTC)
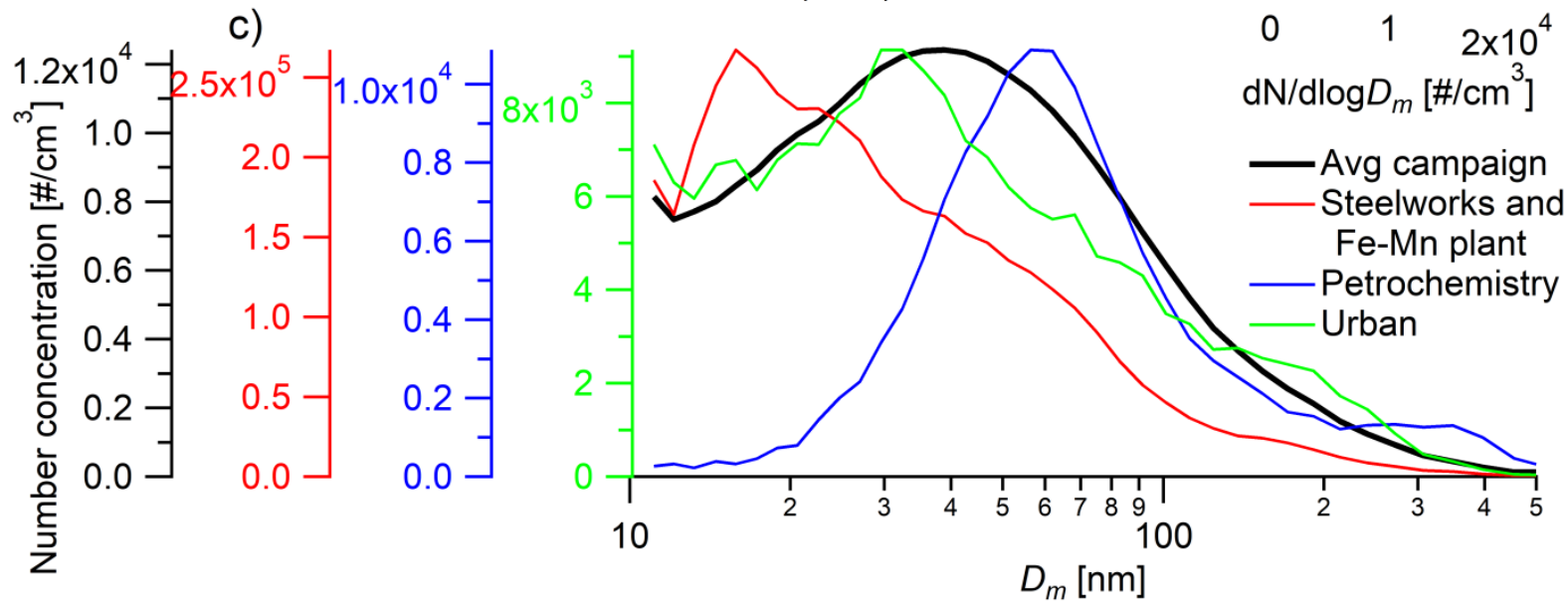